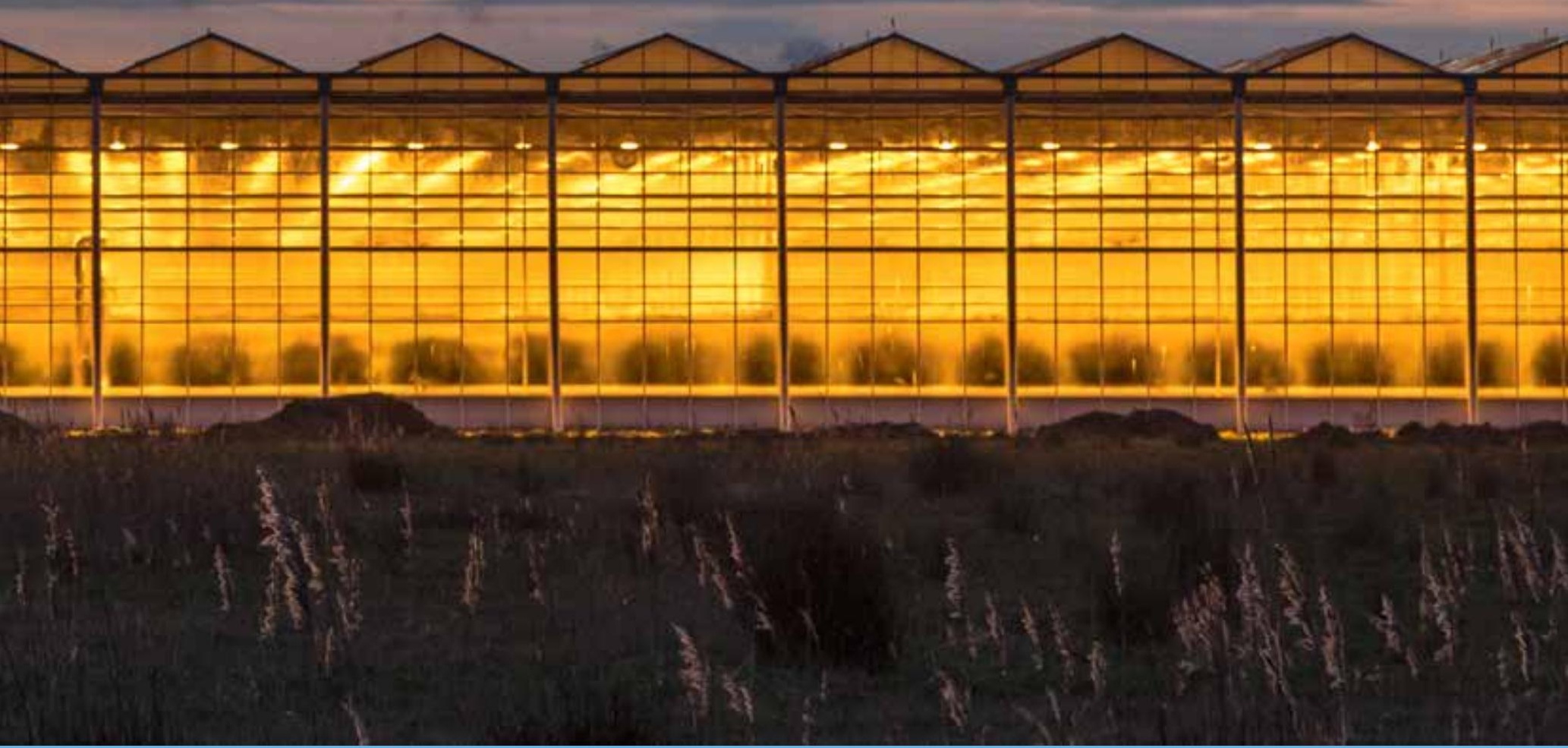

Tariefstijging ODE inkoop elektriciteit: effecten op kosten en $\mathrm{CO}_{2}$-emissie glastuinbouw 



\section{Tariefstijging ODE inkoop elektriciteit: effecten op kosten en $\mathrm{CO}_{2}$-emissie glastuinbouw}

N.J.A. van der Velden, P.X. Smit en R.W. van der Meer

Dit onderzoek is uitgevoerd door Wageningen Economic Research in opdracht van en gefinancierd door het ministerie van Landbouw, Natuur en Voedselkwaliteit, in het kader van het Beleidsondersteunend onderzoeksthema 'Energie en $\mathrm{CO}_{2}$ ' (BO-59-004-004)

Wageningen Economic Research

Wageningen, juni 2020

RAPPORT

2020-044

ISBN 978-94-6395-412-9 
N.J.A. van der Velden, P.X. Smit en R.W. van der Meer, 2020. Tariefstijging ODE inkoop elektriciteit: effecten op kosten en $\mathrm{CO}_{2}$-emissie glastuinbouw. Wageningen, Wageningen Economic Research, Rapport 2020-044. 38 blz.; 7 fig.; 5 tab.; 11 ref.

Op inkoop van elektriciteit wordt in Nederland Opslag Duurzame Energie (ODE) geheven. De ODEtarieven zijn in 2020 verhoogd. Naast kosteneffecten heeft dit voor de glastuinbouw een remmend effect op de gewenste reductie van de $\mathrm{CO}_{2}$-emissie. In de glastuinbouw zijn de kosteneffecten op sectorniveau beperkt van omvang. Door de grote verschillen tussen de afzonderlijke vestigingen geeft het gemiddelde effect per vestiging echter een onvolledig inzicht in de effecten per vestiging. Vestigingen met belichting worden geconfronteerd met de hoogste kostenstijging en het grootste effect op het bedrijfsresultaat. De ODE-verhoging brengt ook voor bedrijven met meerdere vestigingen en voor vestigingen met vergaande of volledige reductie van de $\mathrm{CO}_{2}$-emissie extra kosten met zich mee.

Trefwoorden: Opslag Duurzame Energie, inkoop elektriciteit, groeilicht, warmtekrachtkoppeling, reductie $\mathrm{CO}_{2}$-emissie, duurzame energie, inkoop warmte en glastuinbouw.

Dit rapport is gratis te downloaden op https://doi.org/10.18174/522453 of op www.wur. nl/economicresearch (onder Wageningen Economic Research publicaties).

(C) 2020 Wageningen Economic Research

Postbus 29703, 2502 LS Den Haag, T 07033583 30, E communications.ssg@wur.nl, www.wur.nl/economic-research. Wageningen Economic Research is onderdeel van Wageningen University \& Research.

\section{(cc) BY-NC}

Dit werk valt onder een Creative Commons Naamsvermelding-Niet Commercieel 4.0 Internationaallicentie.

(C) Wageningen Economic Research, onderdeel van Stichting Wageningen Research, 2020

De gebruiker mag het werk kopiëren, verspreiden en doorgeven en afgeleide werken maken. Materiaal van derden waarvan in het werk gebruik is gemaakt en waarop intellectuele eigendomsrechten berusten, mogen niet zonder voorafgaande toestemming van derden gebruikt worden. De gebruiker dient bij het werk de door de maker of de licentiegever aangegeven naam te vermelden, maar niet zodanig dat de indruk gewekt wordt dat zij daarmee instemmen met het werk van de gebruiker of het gebruik van het werk. De gebruiker mag het werk niet voor commerciële doeleinden gebruiken.

Wageningen Economic Research aanvaardt geen aansprakelijkheid voor eventuele schade voortvloeiend uit het gebruik van de resultaten van dit onderzoek of de toepassing van de adviezen.

Wageningen Economic Research is ISO 9001:2015 gecertificeerd.

Wageningen Economic Research Rapport 2020-044 | Projectcode 2282200500

Foto omslag: Shutterstock 


\section{Inhoud}

Woord vooraf $\quad 5$

$\begin{array}{ll}\text { Samenvatting } & 6\end{array}$

S.1 Belangrijkste uitkomsten $\quad 6$

$\begin{array}{lll}\text { S.2 Overige uitkomsten } & 7\end{array}$

$\begin{array}{lll}\text { S.3 Verantwoording } & 8\end{array}$

1

$\begin{array}{ll}\text { Inleiding } & 9\end{array}$

$1.1 \mathrm{CO}_{2}$-emissie glastuinbouw $\quad 9$

1.2 ODE inkoop elektriciteit 9

$\begin{array}{lll}1.3 & \text { Energievraag en -voorziening glastuinbouw } & 10\end{array}$

$\begin{array}{lll}1.4 & \text { Doelstelling en afbakening } & 10\end{array}$

1.5 Aanpak 11

1.5.1 Kwantificering kosteneffecten 11

1.5.2 Analyse reductie $\mathrm{CO}_{2}$-emissie 12

$\begin{array}{llr}2 & \text { Kosteneffecten van ODE-verhoging } & 14\end{array}$

2.1 Inleiding 14

2.2 Extra kosten sectorniveau 14

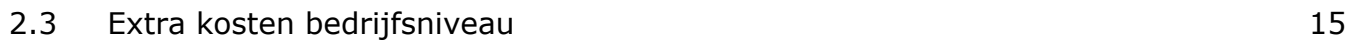

2.3.1 Alle vestigingen $\quad 15$

$\begin{array}{ll}\text { 2.3.2 Groepen vestigingen } & 17\end{array}$

$\begin{array}{lll}2.4 & \text { Effecten op kosten, rentabiliteit en bedrijfsresultaat } & 21\end{array}$

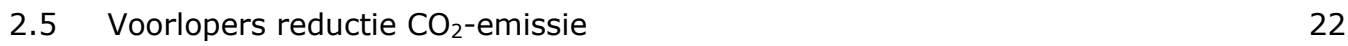

$3 \quad$ Effecten $\mathrm{CO}_{2}$-emissie $\quad 24$

$\begin{array}{lll}3.1 & \text { Inleiding } & 24\end{array}$

$\begin{array}{lll}3.2 & \text { Huidige situatie } & 24\end{array}$

3.3 Prognoses $2030 \quad 24$

3.4 Transitiepad naar $2030 \quad 25$

$\begin{array}{lll}3.5 & \text { ODE-stijging } & 25\end{array}$

3.5.1 Reactie op kostenstijging $\quad 25$

3.5.2 Effecten reductie $\mathrm{CO}_{2}$-emissie $\quad 28$

4

$\begin{array}{ll}\text { Conclusies } & 31\end{array}$

$\begin{array}{ll}\text { Literatuur en websites } & 33\end{array}$

Bijlage 1 Tarieven ODE

Bijlage 2 Gewas(groep)indeling rekenmodel 35

$\begin{array}{lll}\text { Bijlage } 3 \text { Handelingsmogelijkheden } & 36\end{array}$ 



\section{Woord vooraf}

Ter vermindering van de uitstoot van broeikasgassen wordt in Nederland subsidie verstrekt op de productie en distributie van duurzame energie via de Stimulering Duurzame Energie (SDE). Ter financiering van deze regeling wordt op inkoop van elektriciteit en aardgas Opslag Duurzame Energie (ODE) geheven. Hierbij ontstaat de vraag hoe de benodigde belastingen in redelijkheid en met maatschappelijk draagvlak kunnen worden geïnd.

De tariefstructuur van de ODE bestaat uit staffels en is degressief. De tarieven zijn in 2020 aangepast. Om tot een eerlijkere lastenverdeling te komen heeft het kabinet, als onderdeel van het Klimaatakkoord, de ODE aangepast ten gunste van de huishoudens. Dit is gedaan door de tarieven per staffel zodanig aan te passen dat de grootverbruikers, waaronder de industrie en glastuinbouw, meer ODE gaan betalen.

Met het oog op klimaatmitigatie zijn vele partijen waaronder de glastuinbouw actief om de uitstoot van broeikasgassen te reduceren. De glastuinbouw en de overheid zijn een doel overeengekomen voor de $\mathrm{CO}_{2}$-emissie in 2020 en vanuit het Klimaatakkoord is een doel voor 2030 van belang. Bovendien heeft de glastuinbouw de ambitie om in 2040 geen $\mathrm{CO}_{2}$ meer uit te stoten. In het innovatieprogramma Kas als Energiebron ( $\mathrm{KaE}$ ) werken glastuinbouw en overheid samen om reductie van de $\mathrm{CO}_{2}$-emissie te realiseren.

De ministeries van Landbouw, Natuur en Voedselkwaliteit (LNV) en Economische Zaken en Klimaat (EZK) hebben aan Wageningen Economic Research gevraagd om de gevolgen van de ODE-wijziging voor de glastuinbouw na te gaan, met name de kosteneffecten en de invloed op de reductie van de $\mathrm{CO}_{2}$-emissie, in 2020 en in de toekomst.

Het onderzoek is uitgevoerd door Nico van der Velden (projectleider), Pepijn Smit en Ruud van der Meer. De begeleidingscommissie bestond uit J.A.M. Mourits (ministerie van LNV), J.A.J. van Himbergen (ministerie van LNV), D.K.A.M Minten (ministerie van EZK), K.M.A. Wedage (ministerie van EZK), M. Haring (ministerie van EZK), J. Hendriks (ministerie van EZK) en D.K.A.M. Minten (ministerie EZK), H. Roodbeen (ministerie van EZK) en R.P.A. van der Valk (Glastuinbouw Nederland)

Dit onderzoek is uitgevoerd in de periode maart-begin april 2020. Effecten van de coronacrisis zijn niet in beschouwing genomen.

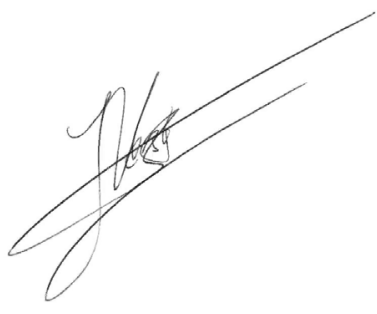

Prof.dr.ir. J.G.A.J. (Jack) van der Vorst Algemeen Directeur Social Sciences Group (SSG) Wageningen University \& Research

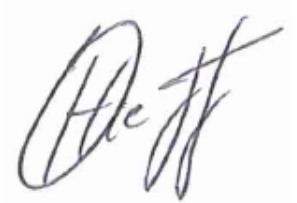

Ir. O. (Olaf) Hietbrink

Business Unit Manager Wageningen Economic Research Wageningen University \& Research 


\section{Samenvatting}

\section{S.1 Belangrijkste uitkomsten}

Beperkte kostenverhoging op sectorniveau

Door de veranderingen van de ODE-tarieven op inkoop van elektriciteit in 2020 nemen de kosten van de glastuinbouwsector met minimaal $€ 30$ miljoen toe. Per vestiging nemen de ODE-kosten met gemiddeld $€ 9.300(+153 \%$ ) toe (tabel S.1). Op sectorniveau zijn deze gemiddelde effecten beperkt van omvang. Echter, door de grote verschillen tussen de afzonderlijke vestigingen geeft het gemiddelde effect per vestiging een onvolledig inzicht in de effecten op bedrijfsniveau.

Tabel S.1 Overzicht structuurkenmerken, gemiddelde inkoop van elektriciteit en ODE-kosten inkoop van elektriciteit en de spreiding bij de bij de extra ODE-kosten van de glastuinbouwsector en per subgroep a)

\begin{tabular}{|c|c|c|c|c|}
\hline \multirow[t]{3}{*}{ Grootheid } & \multirow[t]{3}{*}{ Eenheid } & \multicolumn{2}{|c|}{ Subgroep } & \multirow[t]{3}{*}{ Totaal } \\
\hline & & zonder & met & \\
\hline & & belichting & belichting & \\
\hline Aantal vestigingen & aantal & 2.466 & 709 & 3.175 \\
\hline Areaal glastuinbouw & ha & 5.363 & 3.627 & 8.990 \\
\hline Inkoop & miljoen kWh/jaar & 306 & 2.594 & 2.900 \\
\hline Inkoop & miljoen kWh/vestiging & 0,12 & 3,66 & 0,91 \\
\hline \multicolumn{5}{|l|}{ ODE-kosten elektriciteit } \\
\hline 2020 (minimaal) & miljoen $€$ & 8 & 41 & 49 \\
\hline \multirow[t]{2}{*}{ Spreiding extra kosten } & $€ /$ vestiging laagste 5 & 0 & 200 & 0 \\
\hline & $€ /$ vestiging hoogste 5 & 29.000 & 136.000 & 136.000 \\
\hline
\end{tabular}

a) Glastuinbouwbedrijven kunnen bestaan uit meerdere vestigingen en de ODE wordt in rekening gebracht per vestiging waardoor voor het kwantificeren van de extra kosten de insteek per vestiging is gekozen.

Op basis van de verwachte tarieven voor 2025 nemen de totale kosten voor de sector in 2025 ten opzichte van 2019 toe met minimaal $€ 46$ miljoen. De gemiddelde kostenstijging per vestiging in 2025 ten opzichte van 2019 bedraagt $€ 14.300$ (+235\%). In 2025 liggen de verwachte extra kosten daarmee circa $50 \%$ hoger dan in 2020. De kostenstijging door de tariefwijziging van de ODE is structureel.

Grote kostenverhoging bij vestigingen met belichting

Vestigingen met belichting worden geconfronteerd met de hoogste en vestigingen zonder belichting met de laagste kostenstijging (tabel S.1). Dit geldt zowel voor de situatie met als zonder wkk. De gemiddelde extra ODE-kosten liggen voor de vestigingen met belichting een factor 24 hoger dan bij de vestingen zonder belichting. Voor vestigingen zonder belichting ( $78 \%$ van de vestigingen en $60 \%$ van het areaal) bedraagt de kostenstijging in 2020 gemiddeld $€ 1.500$ (+95\%), uiteenlopend van $€ 0$ tot $€ 29.000$ ( $+166 \%$ ). Voor vestigingen met belichting (22\% van de vestigingen en $40 \%$ van het areaal) bedraagt de kostenstijging in 2020 gemiddeld $€ 36.500$ ( $+167 \%)$, uiteenlopend van $€ 200(+39 \%)$ tot $€ 136.000$ ( $+175 \%)$. Binnen de groep met belichting heeft $69 \%$ van de vestigingen met daarop $88 \%$ van het areaal extra ODE-kosten die boven het gemiddelde van de gehele sector liggen ( $€ 51.000$ ten opzichte van $€$ 9.300). Voor het grootste deel van het areaal met belichting zijn de kosteneffecten dus substantieel. 
Vermindering reductie $\mathrm{CO}_{2}$-emissie

De verhoging van de ODE-kosten voor inkoop van elektriciteit heeft impact op diverse aspecten die van invloed zijn op het reduceren van de $\mathrm{CO}_{2}$-emissie. Dit geldt met name voor de vestigingen met de grootste kostenstijging ofwel de vestigingen met belichting.

Deze vestigingen kunnen reageren op de kostenstijging door extensivering van de belichting en extra gebruik van de wkk's. De mogelijkheden van deze twee opties zijn door verstoringen in de afzetmarkt en mogelijke benutting van de geproduceerde wkk-warmte echter beperkt. De eigen productie van elektriciteit met wkk zal op de vestigingen met belichting wel steviger verankerd blijven. Hierdoor zal de ingezette transitie naar uitfasering van wkk in combinatie met de gewenste toename van inkoop van elektriciteit, het gebruik van duurzame warmte en de inkoop van warmte worden geremd. Doordat bestaande wkk's gereviseerd of vervangen zullen worden door nieuwe geldt dit voor een

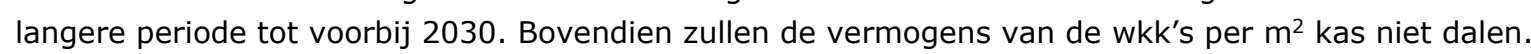
Hierdoor komt ook de warmtebesparing in de knel.

Naast de hiervoor genoemde directe effecten zijn er ook indirecte effecten die de reductie van de $\mathrm{CO}_{2}-$ emissie verminderen. Reductie van de $\mathrm{CO}_{2}$-emissie door energiebesparing en productie van duurzame energie brengt extra elektriciteitsgebruik met zich mee en door de ODE-verhoging ook extra kosten. Voor samenwerkingspartners die nodig zijn voor het realiseren van energievoorzieningen zonder $\mathrm{CO}_{2}$ emissie en bijbehorende energie-infrastructuur vermindert de hoeveelheid af te zetten warmte en ook de waarde hiervan. Hiermee vermindert het investeringsperspectief en het animo voor participatie. Bovendien kunnen glastuinbouwbedrijven minder investeren door de stijging van de kosten en het verminderde bedrijfsresultaat.

Door de directe en indirecte effecten is het effect van de kostenstijging van de ODE op inkoop van elektriciteit tegengesteld aan de gewenste reductie van de $\mathrm{CO}_{2}$-emissie van glastuinbouw. De reductie zal daardoor stagneren en mogelijk kan de $\mathrm{CO}_{2}$-emissie zelfs toenemen. Het kwantitatieve effect van alleen de directe effecten op vestigingen met belichting op de reductie van de $\mathrm{CO}_{2}$-emissie loopt globaal uiteen van minus 0,5 tot minus 0,7 Mton. Dit is 15 tot $27 \%$ van de geprognotiseerde reductie van de $\mathrm{CO}_{2}$-emissie van de glastuinbouw in 2030 .

\section{S.2 Overige uitkomsten}

Uiteenlopende kostenstijgingen

Bij zowel vestigingen met als zonder belichting heeft circa een derde van de vestigingen met circa tweederde van het areaal een kostenstijging die boven het gemiddelde per subgroep ligt. De gemiddelde kostenstijging voor deze vestigingen ligt ruim 2 maal hoger dan het gemiddelde per subgroep.

Een deel van de bedrijven heeft meerdere vestigingen. Voor deze bedrijven ligt de absolute kostenstijging evenredig hoger en de relatieve kostenstijging beperkt hoger. Dit laatste komt doordat de ODE-kosten per vestiging in rekening worden gebracht en voor de bedrijven met meerdere vestigingen in 2019 al hoger waren.

Vestigingen die vergaande of volledige reductie van de $\mathrm{CO}_{2}$-emissie hebben gerealiseerd kopen meer elektriciteit in. Dit komt door de extra elektriciteit die nodig is voor duurzame energiebronnen en energiebesparende technieken, maar ook doordat elektriciteit die in de situatie zonder vergaande of volledige reductie van de $\mathrm{CO}_{2}$-emissie opgewekt werd met wkk en nu ingekocht moet worden. Dit brengt voor de meeste vestigingen substantiële extra ODE-kosten met zich mee in vergelijking met gangbare vestigingen. De extra ODE-kosten liggen voor de voorlopers in 2020 ten opzichte van 2019 gemiddeld $262 \%$ hoger dan in de referentiesituatie.

In 2025 zijn de extra kosten ten opzichte van 2019 voor de vestigingen met belichting gemiddeld $€ 55.500(+254 \%)$ en voor de vestigingen zonder belichting gemiddeld $€ 2.500(+159 \%)$ toe. Dit is respectievelijk 52\% en $67 \%$ hoger dan de kostenstijging in 2020. 


\section{Effecten rentabiliteit en bedrijfsresultaat}

Door de hogere ODE-kosten op inkoop van elektriciteit nemen de totale kosten van de glastuinbouwbedrijven toe met gemiddeld $0,6 \%$. De netto-energiekosten stijgen met gemiddeld $4 \%$. De gemiddelde rentabiliteit zal met 0,6 procentpunt dalen en het gemiddelde netto bedrijfsresultaat met $6 \%$.

Bij de bedrijven met belichting zijn de effecten op de kosten en de economische bedrijfsresultaten beduidend groter. De genoemde kentallen liggen bij deze bedrijven een factor 5 tot 10 ongunstiger ten opzichte van de subgroep zonder belichting. Bij de laatste groep daalt het bedrijfsresultaat met circa $2 \%$ en bij de eerste groep met circa $11 \%$.

De vestigingen met de meer intensief belichte gewassen chrysant, Lisianthus, roos en tomaat worden geconfronteerd met de grootste kostenstijging. Het aandeel van de extra kosten in de omzet loopt bij deze gewassen uiteen van bijna $1 \%$ tot ruim $2 \%$. Deze aandelen liggen een factor 1,5 tot 4 hoger in vergelijking met de gemiddelde kostenstijging in de gehele bedrijfstak $(0,6 \%)$ en ook hoger in vergelijking met alle bedrijven met belichting. Dit betekent dat de bedrijfsresultaten bij deze gewassen met intensieve belichting sterker negatief worden beïnvloed.

\section{S.3 Verantwoording}

Voor de kwantificering van de kosteneffecten is gebruikgemaakt van data over het areaal per gewas op vestigingsniveau uit de Landbouwtelling 2018 van het CBS en over de inkoop van elektriciteit per $\mathrm{m}^{2}$ per gewas vanuit de Energiemonitor glastuinbouw van Wageningen Economic Research (Van der Velden en Smit, 2019b). Op basis van deze input is een rekenmodel ontwikkeld waarmee de kosteneffecten op vestigingsniveau en op sectorniveau en de effecten op de bedrijfsresultaten (zie www.agrimatie.nl) zijn gekwantificeerd. Bij de spreiding van de effecten is naast het onderscheid tussen niet en wel belichten ook gekeken naar bedrijven met meerdere vestigingen en de voorlopers bij de reductie van de $\mathrm{CO}_{2}$-emissie. Voor de effecten op de reductie van de $\mathrm{CO}_{2}$-emissie is voortgebouwd op de prognoses van de $\mathrm{CO}_{2}$-emissie van de glastuinbouw 2030 (Van der Velden et al., 2018). 


\section{$1 \quad$ Inleiding}

\section{$1.1 \quad \mathrm{CO}_{2}$-emissie glastuinbouw}

De energievraag van de glastuinbouw wordt in de actuele situatie voor een groot deel gedekt door aardgas. Aardgasverbruik brengt $\mathrm{CO}_{2}$-emissie met zich mee. Bezien vanuit het broeikaseffect en het Klimaatakkoord is het verlagen van de $\mathrm{CO}_{2}$-emissie van groot belang. Tussen de overheid en de glastuinbouwsector is een doelstelling voor de $\mathrm{CO}_{2}$-emissiereductie voor 2020 overeengekomen (Convenant, 2011) (Meerjarenafspraak, 2014) (brief 2017). In het Klimaatakkoord is een $\mathrm{CO}_{2}-$ emissiedoelstelling voor 2030 voor de glastuinbouw van belang. De $\mathrm{CO}_{2}$-emissie wordt bepaald met de IPPC-methode. Reductie van de $\mathrm{CO}_{2}$-emissie kan worden gerealiseerd door:

- energiebesparing, ofwel het verlagen van de energievraag (warmte en elektriciteit)

- energievoorziening zonder $\mathrm{CO}_{2}$-emissie,

- gebruik duurzame energie (warmte en elektriciteit, eigen productie en inkoop),

- inkoop warmte en elektriciteit uit niet-duurzame bronnen van derden.

\subsection{ODE inkoop elektriciteit}

Op de inkoop van aardgas en elektriciteit wordt Energiebelasting (EB) en Opslag duurzame energie (ODE) geheven. De tariefstructuur van beide heffingen bestaat uit meerdere staffels (bijlage 1). De ODE is ingevoerd om de uitgaven voor de Stimulering Duurzame Energie (SDE+) te financieren. Volgens informatie van EZK is sinds 2012 daarbij een verdeling tussen huishoudens en bedrijven van $50 / 50$ gehanteerd. Om tot een eerlijkere verdeling van de lasten te komen heeft het kabinet, als onderdeel van het Klimaatakkoord, de lastenverdeling van de ODE aangepast ten gunste van de huishoudens. Dit is gedaan door de tarieven per staffel vanaf 2020 zodanig aan te passen dat de grootverbruikers meer ODE gaan betalen. Volgens informatie van EZK betalen de huishoudens vanaf $202033 \%$ van de ODE en de bedrijven $67 \%$.

Uit een globale berekening van de effecten van de wijziging van de tarieven in 2020 voor de glastuinbouwsector blijkt dat de ODE-kosten voor inkoop van elektriciteit en voor inkoop aardgas in 2020 stijgen. De kostenstijging voor aardgas is voor de glastuinbouw minder dan een tiende van de kostenstijging voor elektriciteit. ${ }^{1}$ Bovendien is het aardgasverbruik waarover ODE wordt geheven gelijkmatiger verdeeld over de vestigingen dan de inkoop van elektriciteit.

Voor de glastuinbouw is de verhoging van de ODE-tarieven voor inkoop van elektriciteit in 2020 dus het meest relevant. De verhoging is het grootst in de derde staffel. Het effect op de kosten wordt versterkt door het grote bereik van deze derde staffel (van 50 duizend tot 10 miljoen $\mathrm{kWh}$ ). Bij het volledig doorlopen tot en met de derde staffel bedragen de extra kosten in 2020 ruim $€ 130.000$ per vestiging. Hierna volgt nog een vierde staffel (>10 miljoen $\mathrm{kWh}$ ).

Bedrijven kunnen bestaan uit meerdere vestigingen en de ODE wordt in rekening gebracht per vestiging waardoor voor het kwantificeren van de extra kosten de insteek vestigingen gekozen.

1 De kostenstijging voor de glastuinbouw door de aanpassing van de ODE tarieven voor aardgas in 2020 is door Wageningen Economic Research globaal geschat op circa $€ 2$ miljoen en voor inkoop van elektriciteit bedraagt de kostenstijging minimaal $€ 30$ miljoen (hoofdstuk 2). Bij de schatting van de extra ODE-kosten voor aardgas is rekening gehouden met de nationale vrijstelling voor aardgas dat wordt gebruikt in wkk's en met de verlaagde ODE-tarieven op aardgas voor de glastuinbouw. De vrijstelling van wkk-aardgas is ter voorkoming van dubbele belasting; ODE-heffing vindt immers al plaats bij de inkoop van de geproduceerde elektriciteit door de afnemer. Zonder verlaagde ODE-tarieven op aardgas zou de glastuinbouw door de energie-intensiteit en de kleinschalige structuur in combinatie met het degressieve tariefstelsel een sterkere energiebelastingdruk ondervinden dan andere energie-intensieve sectoren

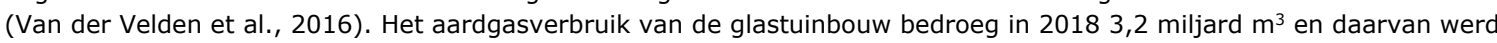
circa $84 \%$ gebruikt in wkk's (Van der Velden en Smit, 2019b). 
Vestigingen die veel elektriciteit inkopen, krijgen de grootste kostenstijging door de wijziging van de ODE. In de glastuinbouw zijn dit vooral de vestigingen met belichting. De kostenstijging voor deze vestigingen hangt af van de verhouding tussen de eigen elektriciteitsopwekking met wkk en de inkoop van elektriciteit.

\subsection{Energievraag en -voorziening glastuinbouw}

Het netto-energiegebruik door de glastuinbouw was in 2018 zo'n 100 PJ (Van der Velden en Smit, $2019 b)$ en bestond voor een groot deel uit aardgas (3,2 miljard $\left.\mathrm{m}^{3}\right)$. Dit aardgas wordt gebruikt in wkk's en ketels. Het gebruik van duurzame energie (7\%) en inkoop warmte (3\%) is nog beperkt van omvang. Met aardgas-wkk's wordt met nuttig gebruik van de geproduceerde warmte, elektriciteit geproduceerd voor eigen consumptie (40\%) en voor de verkoop (60\%). Aanvullend op de eigen productie wordt er elektriciteit ingekocht (circa $40 \%$ van de consumptie).

De elektriciteitsconsumptie, circa 6,6 miljard kWh in 2018 (Van der Velden en Smit, 2019b), wordt voor meer dan $80 \%$ gebruikt voor de inzet van groeilicht, het resterende deel voor overige elektrische apparatuur, waaronder bedrijfsvoorzieningen, duurzame energie en teeltconditionering

(Van der Velden en Smit, 2013).

De EB en ODE voor elektriciteit worden geheven op inkoop. De inkoop van elektriciteit door de glastuinbouw bedroeg in 2018 gemiddeld $32 \mathrm{kWh}$ per $\mathrm{m}^{2}$ kas per jaar. Er zijn echter nauwelijks vestigingen met deze gemiddelde inkoop: de spreiding per vestiging loopt globaal uiteen van 1 tot $500 \mathrm{kWh}$ per $\mathrm{m}^{2}$. Daarbij komt dat de vestigingsomvang globaal uiteenloopt van zeer klein (100 $\mathrm{m}^{2}$ kas) tot zeer groot (100 ha kassen). Deze combinatie resulteert in een zeer grote spreiding van de aangekochte hoeveelheid elektriciteit. De hoeveelheid ingekochte elektriciteit per vestiging op jaarbasis is bepalend voor de kostenstijging door de ODE-wijziging.

\subsection{Doelstelling en afbakening}

Naast de kosteneffecten heeft de wijziging van de ODE ook effect op de toekomstige reductie van de $\mathrm{CO}_{2}$-emissie van de glastuinbouw. Inkoop van elektriciteit is immers een optie om het aardgasverbruik en dus de $\mathrm{CO}_{2}$-emissie te reduceren en deze inkoop wordt duurder. Hiernaast wordt de vervanging van aardgas-wkk door duurzame warmte of inkoop warmte in combinatie met inkoop van elektriciteit minder aantrekkelijk, omdat de kosten van inkoop van elektriciteit hoger worden. Bovendien is er elektriciteit nodig voor de productie van de duurzame warmte zodat ook de kosten voor duurzame warmte stijgen. De ministeries van LNV en EZK hebben aan Wageningen Economic Research gevraagd om de effecten van de wijziging van de ODE op elektriciteit in 2020 en in de toekomst (2025/2030) in beeld te brengen voor de glastuinbouw.

De doelstelling van dit project is tweeledig:

1. Het verkrijgen van kwantitatief inzicht in de effecten van de ODE-tariefwijziging op inkoop van elektriciteit op de kosten, de rentabiliteit en het bedrijfsresultaat van de glastuinbouw. Meer in het bijzonder is de vraag in hoeverre deze effecten per bedrijf verschillen.

2. Het verkrijgen van inzicht in de effecten op de ontwikkeling van de $\mathrm{CO}_{2}$-emissie van de glastuinbouw.

\section{Afbakening}

- Dit project heeft alleen betrekking op de glastuinbouw.

- Het inzicht in de effecten op de ontwikkeling van de $\mathrm{CO}_{2}$-emissie betreft de reductie van de $\mathrm{CO}_{2}$ emissie en dus niet de absolute emissie.

- In dit project wordt enkel de tariefwijziging van de ODE op inkoop van elektriciteit in 2020 en 2025 in beschouwing genomen, niet die van aardgas en niet de tarieven van andere jaren. 
- In de toekomst kunnen er andere relevante wijzigingen optreden in het fiscaal regime zoals bij de $\mathrm{EB}$, de ODE en eventueel een $\mathrm{CO}_{2}$-heffing. Deze wijzigingen zijn geen onderdeel van de analyses in dit project.

- Effecten op de opbrengsten van de glastuinbouwproducten zijn niet in beschouwing genomen.

- Ondernemers kunnen reageren op de extra kosten door ODE-tariefswijzigingen waardoor het kosteneffect kan verminderen. Deze effecten zijn niet in beschouwing genomen bij de kosteneffecten, maar wel bij de ontwikkeling van de reductie van de $\mathrm{CO}_{2}$-emissie.

\section{Definities}

Onder glastuinbouw wordt verstaan het totaal areaal glastuinbouw in Nederland op basis van de Landbouwtelling (LBT) van het CBS. Dit betreft glastuinbouwareaal op bedrijven met glastuinbouw. Dit is zowel glastuinbouwareaal op gespecialiseerde glastuinbouwbedrijven als glastuinbouwareaal op bedrijven met een andere hoofdactiviteit.

De $\mathrm{CO}_{2}$-emissie wordt bepaald met de IPCC-methode. Bij de IPCC-methode wordt het totale fossiele brandstofverbruik van de glastuinbouw in beschouwing genomen en wordt er geen temperatuurcorrectie toegepast (Van der Velden en Smit, 2019c). De $\mathrm{CO}_{2}$-emissie van de glastuinbouw omvat daarmee naast de emissies die samengaan met de productie van warmte (ketels en wkk) ook de emissies die voortkomen uit de productie van elektriciteit met aardgas-wkk's voor eigen consumptie en voor verkoop. De emissies van de glastuinbouw zijn exclusief emissies van andere sectoren waarvan energie wordt ingekocht (warmte en elektriciteit) en inkoop van $\mathrm{CO}_{2}$ van partijen buiten de glastuinbouwsector.

\subsection{Aanpak}

\subsubsection{Kwantificering kosteneffecten}

Voor het bepalen van de kosteneffecten op sector- en bedrijfsniveau is als eerste stap een rekenmodel ontwikkeld. In dit model is voortgebouwd op het conceptueel ontwerp dat ten grondslag ligt aan het bestaande model voor Energie Belasting (EB) op aardgas voor de glastuinbouw (Van der Velden en van der Meer, 2014) en dat onder andere is toegepast voor de Evaluatie van het de verlaagde energiebelastingtarief voor de glastuinbouw door LEI Wageningen UR en CE Delft (Van der Velden et al., 2016). Het ontwikkelde model voor elektriciteit is hieronder uiteengezet.

De ODE wordt in rekening gebracht per aansluiting. Uitgegaan wordt van één aansluiting per vestiging. De gestaffelde tariefstructuur moet dus per vestiging doorlopen worden met de hoeveelheid inkoop van elektriciteit.

Met het model zijn de kosteneffecten per vestiging gekwantificeerd en deze zijn geaggregeerd naar sectorniveau. Vervolgens zijn de kenmerken van de vestigingen die te maken krijgen met een beperkte kostenstijging en die geconfronteerd worden met een grote kostenstijging geanalyseerd.

Tot slot zijn de extra ODE-kosten voor de bedrijven met meerdere vestigingen en voor de bedrijven die geen $\mathrm{CO}_{2}$ uitstoten geanalyseerd. De bedrijven met meerdere vestigingen doorlopen de ODEstaffels per vestiging. De voorlopers gebruiken geen fossiele brandstoffen maar kopen wel meer elektriciteit in. Extra elektriciteit is nodig voor energiebesparing en duurzame energievoorzieningen. Bovendien wordt de elektriciteit die voorheen werd geproduceerd met aardgas-wkk's nu ingekocht. De extra ODE-kosten van vier voorlopers zijn in beeld gebracht.

\section{Rekenmodel}

Het model bestaat uit de volgende bouwstenen:

- Vanuit de CBS Landbouwtelling (LBT) zijn bij Wageningen Economic Research voor de glastuinbouw data beschikbaar over het areaal kas per gewas(groep) en het gebruik van belichting en wkk op bedrijfsniveau. Deze data uit de LBT van het meest recent beschikbare jaar 2018 is de basis-input voor het model. 
- Niet duidelijk is of in de LBT vestigingen of bedrijven of een mix hiervan zijn opgenomen. Diverse signalen geven aan dat dit waarschijnlijk vooral vestigingen zijn. Ook zijn er signalen dat de LBT niet volledig dekkend is voor het totaal areaal glastuinbouw in Nederland. Het resultaat van het onderzoek is op korte termijn gewenst. Daarom wordt voor dit onderzoek verondersteld dat in de LBT alle vestigingen met glastuinbouw zijn opgenomen. ${ }^{2}$

- De vestigingen in de LBT zijn ingedeeld naar gewas(groepen) en daarbinnen naar 4 subgroepen (zonder en met belichting en daarbinnen zonder en met wkk).

- Per subgroep per gewas(groep) zijn vervolgens referentiewaarden vastgesteld voor inkoop van elektriciteit in 2018. De referentiewaarde betreft de gemiddelde inkoop van elektriciteit $\left(\mathrm{kWh} / \mathrm{m}^{2}\right)$ per subgroep per gewas(groep). Hierbij zijn 32 gewas(groepen) onderscheiden (bijlage 2) en is er dus voor 128 subgroepen een referentiewaarde vastgesteld. Hierbij dient opgemerkt te worden dat bepaalde subgroepen bij bepaalde gewas(groepen) zeer beperkt voorkomen.

- Data voor de referentiewaarden is afkomstig vanuit de Energiemonitor glastuinbouw (Van der Velden en Smit, 2019c). Voor een beperkt aantal subgroepen per gewas(groep) is dit niet het geval en is de referentiewaarde gekwantificeerd op basis van informatie uit het project Effect intensivering, extensivering en energiebesparing op $\mathrm{CO}_{2}$-emissie Nederlandse glastuinbouw (Van der Velden een Smit, 2017).

- De referentiewaarden per gewas(groep) per subgroep zijn getoetst door aggregatie van alle referentiewaarden met de bijbehorende arealen uit de LBT. Het resultaat hiervan bleek in grote mate in overeenstemming met de totale inkoop van elektriciteit van de glastuinbouwsector uit de Energiemonitor Glastuinbouw in 2018 (2,8 miljard kWh in 2018). Ook heeft een consistentiecheck plaatsgevonden van referentiewaarden per gewas(groep) van de subgroepen met de beschikbare gemiddelden per gewas(groep) in de Energiemonitor Glastuinbouw.

- Door koppeling van het areaal per gewas(groep) per vestiging aan de referentiewaarden per $\mathrm{m}^{2}$ is de hoeveelheid inkoop van elektriciteit per vestiging gekwantificeerd.

- Tot slot is met deze absolute hoeveelheid inkoop van elektriciteit per vestiging in combinatie met de tarieven van de ODE de kostenstijging per vestiging en op sectorniveau berekend.

Het voorgaande is schematisch weergegeven in figuur 1.1 .

Door Wageningen Economic Research worden jaarlijks de rentabiliteit, de bedrijfsresultaten, de inkomens en de vermogenspositie voor diverse agrarische bedrijfstakken gekwantificeerd in het Bedrijveninformatienet (www.agrimatie. $\mathrm{nl}$ ). De genoemde kentallen worden bepaald voor het totaal van de gespecialiseerde glastuinbouwbedrijven. Deze bedrijven omvatten het totaal areaal glastuinbouw, exclusief het areaal op bedrijven met een andere hoofdactiviteit en de hele kleine bedrijven. $^{3}$

Voor het bepalen van effecten van de ODE-kostenstijging op de rentabiliteit en het bedrijfsresultaat zijn in het hiervoor besproken model, de vestigingen geselecteerd die tot de gespecialiseerde bedrijven behoren. Vervolgens is een vertaalslag gemaakt van de extra kosten voor vestigingen naar de extra kosten voor bedrijven.

\subsubsection{Analyse reductie $\mathrm{CO}_{2}$-emissie}

\section{Reductie $\mathrm{CO}_{2}$-emissie}

In het klimaatakkoord wordt ingezet op een reductie van de $\mathrm{CO}_{2}$-emissie van de glastuinbouw. Op dit transitieproces zijn veel factoren van invloed, zo ook de wijziging van de ODE-tarieven. De effecten van de ODE-verhoging op de ontwikkeling van de $\mathrm{CO}_{2}$-emissie zijn partieel geanalyseerd los van andere invloeden op de ontwikkeling van de $\mathrm{CO}_{2}$-emissie.

\footnotetext{
2 Omdat de LBT niet volledig dekkend is voor het totaal areaal glastuinbouw in Nederland liggen de werkelijke extra kosten op sectorniveau hoger dan berekend met het model. Op basis van informatie van het CBS is het totaal areaal glastuinbouw in 2019 met circa 700 ha (8\%) toegenomen. De basisdata van 2019 waren tijdens de uitvoering het onderzoek nog niet beschikbaar.

3 Het Informatienet omvat gespecialiseerde glastuinbouwbedrijven met een minimum omvang. Bedrijven met glastuinbouw naast een niet-glastuinbouw hoofdactiviteit zijn geen gespecialiseerde glastuinbouwbedrijven. Ook hele kleine bedrijven (met minder dan $€ 25.000$ Standaardopbrengst) blijven buiten beschouwing. Het Informatienet dient primair voor de economische bedrijfsresultaten. De afzonderlijke posten zoals energiekosten geven een globale indicatie.
} 


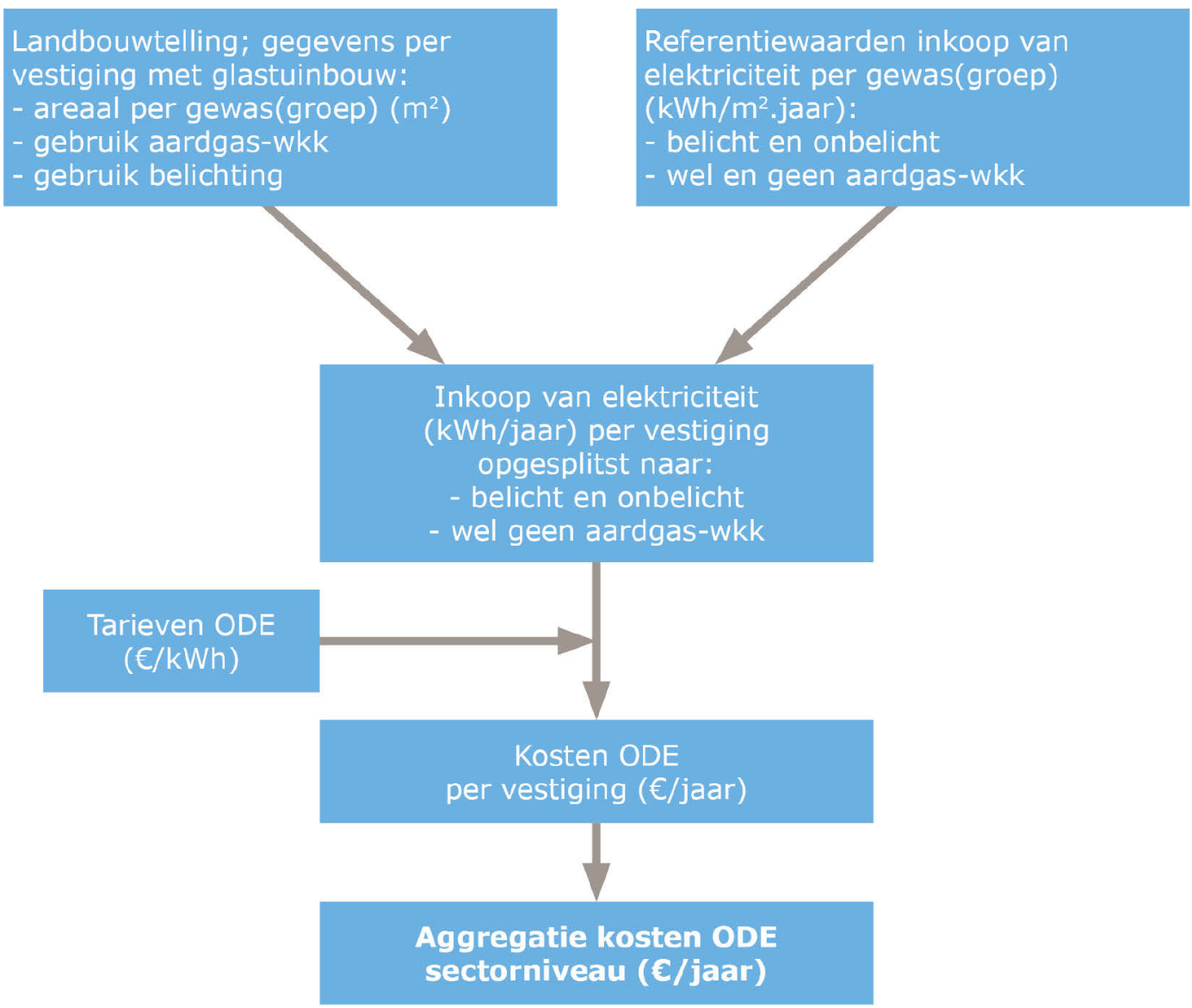

Figuur 1.1 Schematische weergave ODE-model elektriciteit

\section{Economische effecten}

De huidige situatie en de toekomstige situatie rond de $\mathrm{CO}_{2}$-emissie in de glastuinbouw worden op hoofdlijnen beschreven. Voor de huidige situatie is uitgegaan van de Energiemonitor Glastuinbouw 2019 (Van der Velden en Smit, 2019b) en voor de toekomstige situatie is uitgegaan van de Prognoses $\mathrm{CO}_{2}$-emissie glastuinbouw 2030 (Van der Velden et al., 2018). Hieruit volgt een transitiepad naar de toekomst van 2030 .

\section{Effecten op reductie $\mathrm{CO}_{2}$-emissie}

Glastuinbouwondernemers kunnen reageren op de kostenstijging van de ODE. De mogelijkheden hiervoor zijn geïnventariseerd. Daarna is een beeld geschetst van de verwachte reactie door de glastuinbouwondernemers. Daarbij is uitgegaan van de bedrijfstypen die worden geconfronteerd met de grootste kostenstijging. Onderscheid is gemaakt naar de korte termijn (1-2 jaar) (tactisch) en de middellange termijn (1-5 jaar) (strategisch). Voor het in beeld brengen van de mogelijke en verwachte reacties door de glastuinbouwondernemers op de kostenstijging van de ODE is gebruikgemaakt van de expertise bij Wageningen Economic Research en zijn ervaringsdeskundigen in de glastuinbouw geraadpleegd: toeleveranciers, adviseurs en glastuinbouwondernemers. Vervolgens is de verwachte reactie geprojecteerd op de reductie van de $\mathrm{CO}_{2}$-emisse naar 2030. Tot slot zijn een deel van de effecten op de geprognotiseerde reductie van de $\mathrm{CO}_{2}$-emissie in 2030 gekwantificeerd. 


\section{$2 \quad$ Kosteneffecten van ODE-verhoging}

\section{$2.1 \quad$ Inleiding}

In dit hoofdstuk zijn de kosteneffecten van de ODE-verhoging geanalyseerd. Hiervoor zijn als eerste de extra kosten in beeld gebracht. Dit is gedaan op sectorniveau (paragraaf 2.2) en op bedrijfsniveau (paragraaf 2.3). Hierbinnen is onderscheid gemaakt naar alle vestingen met glastuinbouw en specifieke groepen vestigingen. Vervolgens is de invloed van de extra kosten op het rentabiliteit en het bedrijfsresultaat bepaald op bedrijfstakniveau (paragraaf 2.4). Tot slot zijn ook de extra kosten door de ODE-verhoging van de vestigingen die geen $\mathrm{CO}_{2}$ meer uitstoten geanalyseerd (paragraaf 2.5).

\section{Sectorniveau}

De extra kosten op sectorniveau zijn bepaald voor de gehele glastuinbouwsector, ofwel het totaal areaal glastuinbouw in Nederland. De ODE-kosten zijn afhankelijk van de inkoop van elektriciteit per vestiging. Voor de extra kosten op sectorniveau zijn de extra kosten van alle vestigingen met glastuinbouw in de LBT geaggregeerd.

\section{Bedrijfstakniveau}

De invloed van de extra kosten op de rentabiliteit en het bedrijfsresultaat is bepaald voor de gespecialiseerde glastuinbouwbedrijven. De gespecialiseerde bedrijven samen worden de bedrijfstak genoemd en omvatten in 2018 73\% van alle vestigingen met glastuinbouw en $91 \%$ van het areaal glastuinbouw in Nederland.

\subsection{Extra kosten sectorniveau}

Kostenstijging in 2020

De ODE-kosten op elektriciteit bedragen voor de glastuinbouwsector als geheel (laatste kolom tabel 2.1) in 2020 naar schatting minimaal $€ 49$ miljoen en in 2019 minimaal $€ 19$ miljoen. De ODEkosten elektriciteit nemen daarmee in 2020 met minimaal $€ 30$ miljoen toe. Dit is een toename van $153 \%$. Gemiddeld per vestiging is de kostenstijging $€ 9.300$ en gemiddeld per $\mathrm{m}^{2}$ kas 33 eurocent.

\section{Kostenstijging in 2025}

In de toekomst zullen de tarieven voor de ODE verder stijgen. Uitgaande van de door EZK verstrekte ODE-tarieven voor 2025 (bijlage 1), nemen de ODE-kosten elektriciteit op sectorniveau in 2025 toe tot minimaal $€ 65$ miljoen. Ten opzichte van 2019 is dit een kostenstijging van minimaal $€ 46$ miljoen (+235\%). Gemiddeld per vestiging is de kostenstijging $€ 14.300$ en per $\mathrm{m}^{2}$ kas is dit gemiddeld 51 eurocent. De toekomstige kostenstijging in 2025 ligt daarmee ruim 50\% hoger dan de kostenstijging in 2020. De kostenstijging voor inkoop van elektriciteit door de wijziging van de ODEtarieven beperkt zich dus niet tot 2020 en is daarmee structureel.

Opgemerkt dient te worden dat door de schaalvergroting het aantal vestigingen in 2025 kleiner zal zijn waardoor de wekelijke extra kosten op sectorniveau lager zullen zijn. Daarentegen zullen vestigingen ook groter zijn en zal het gebruik van belichting verder toenemen (Van der Velden en Smit, 2018). Hierdoor neemt de inkoop van elektriciteit per vestiging toe en zullen de werkelijke extra kosten op sectorniveau hoger zijn. De effecten van de genoemde twee ontwikkelingen heffen elkaar gedeeltelijk op. 
Tabel 2.1 Overzicht structuurkenmerken, gemiddelde inkoop van elektriciteit, ODE-kosten inkoop van elektriciteit, extra ODE-kosten inkoop van elektriciteit en de spreiding bij de inkoop van elektriciteit en bij de extra ODE-kosten in de glastuinbouwsector en per subgroep

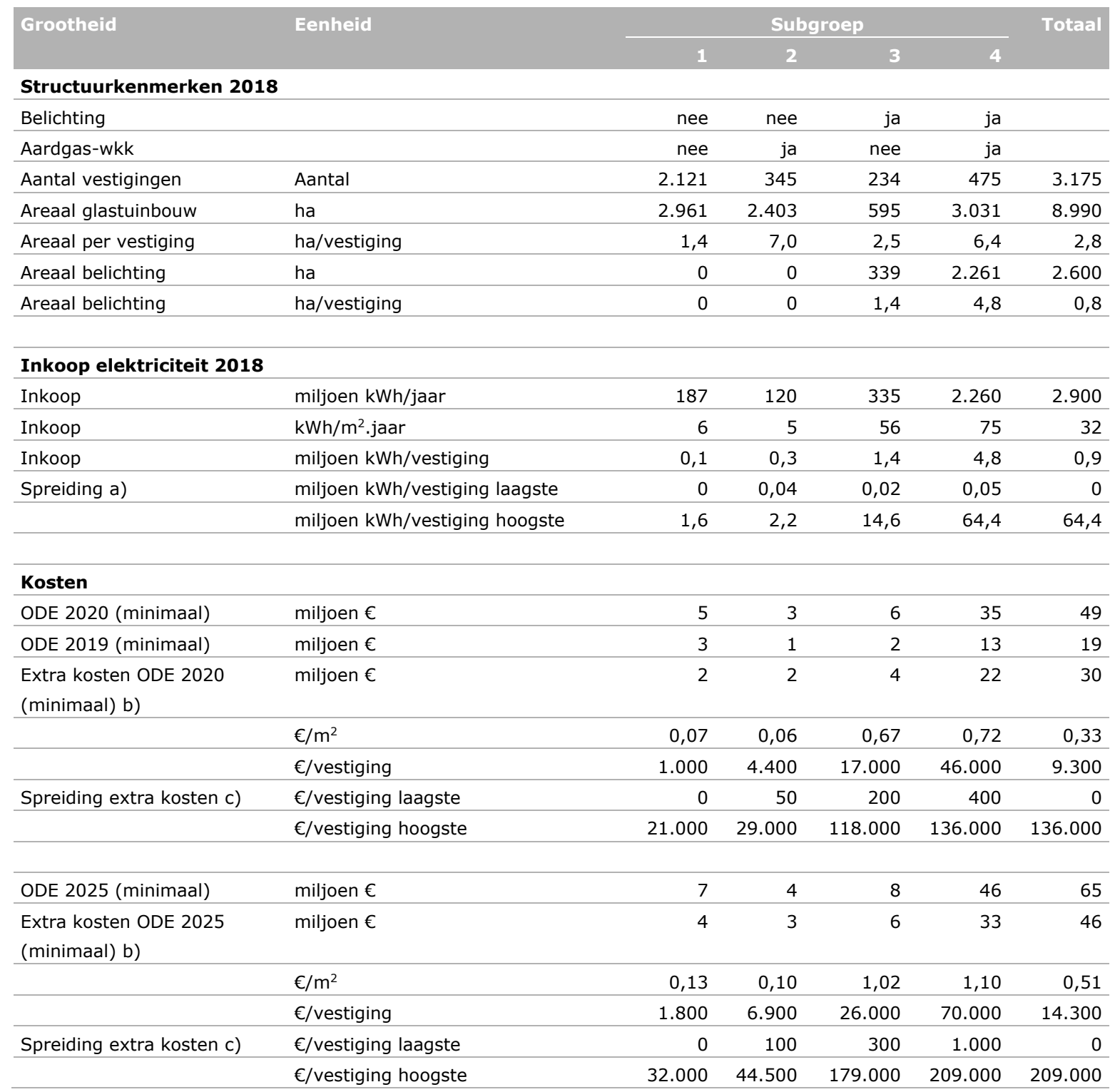

a) Gemiddelde van de 5 vestingen met het laagste en met het hoogste inkoop van elektriciteit; b) Ten opzichte van 2019 c) Gemiddelde van de 5 vestingen met de laagste en met de hoogste extra kosten

\section{Spreiding}

Door de diversiteit in de sector (paragraaf 1.3) bestaan er tussen vestigingen zeer grote verschillen in de absolute hoeveelheid inkoop van elektriciteit. Dit loopt tussen de vestigingen grofweg uiteen van nihil tot 65 miljoen kWh per jaar. Hierdoor geven de gemiddelde effecten op kosten een onvolledig inzicht in de effecten op bedrijfsniveau.

\subsection{Extra kosten bedrijfsniveau}

\subsubsection{Alle vestigingen}

De ODE-kosten worden in rekening gebracht per vestiging. De spreiding van de extra kosten in 2020 door de stijging van de ODE is voor alle vestigingen weergegeven in figuur 2.1. De extra kosten lopen uiteen van nihil tot ruim $€ 140.000(+136 \%)$ per vestiging. Bij deze hoogste absolute extra kosten behoort niet de hoogste relatieve kostenstijging. De hoogste relatieve kostenstijging bedraagt $175 \%$ en behoort bij een vestiging met extra ODE-kosten van ruim $€ 130.000$. 


\section{Meerdere vestigingen per bedrijf}

In de glastuinbouwpraktijk is er een trend van schaalvergroting, niet alleen naar grotere locaties, maar ook naar meer vestigingen per bedrijf. Er zijn bedrijven met meer dan vijf vestigingen en bedrijven met twee of drie vestigingen zijn geen uitzondering. De bedrijven met meerdere vestigingen zijn vaker energie-intensief met intensieve belichting. Zij kopen relatief veel elektriciteit in per $\mathrm{m}^{2} \mathrm{kas}$. Bedrijven met meerdere vestigingen doorlopen per vestiging de ODE-staffels. Voor overeenkomstige bedrijven qua omvang $\left(\mathrm{m}^{2}\right)$ en inkoop van elektriciteit $\left(\mathrm{kWh} / \mathrm{m}^{2}\right)$ liggen de extra absolute ODE-kosten bij meerdere vestigingen per bedrijf evenredig hoger en is de relatieve kostenstijging beperkt hoger. Dit laatste komt doordat de ODE-kosten in 2019 al op een substantieel hoger niveau lagen.

\section{Inkoop elektriciteit, belichting en wkk}

De grootste kostenstijging vindt plaats op vestigingen die veel elektriciteit inkopen. Ruim $80 \%$ van de elektriciteitsconsumptie op sectorniveau wordt ingezet voor groeilicht (Van der Velden en Smit, 2013). De vestigingen met de grootste inkoop van elektriciteit zijn dus de vestigingen met belichting. Op circa $30 \%$ van het totaal areaal glastuinbouw werd in 2018 belichting toegepast. Op een deel van het areaal van de vestigingen met belichting vindt ook teelt zonder belichting plaats. Het areaal van de vestigingen met belichting omvat circa $40 \%$ van het totaal areaal glastuinbouw. Sinds de introductie van groeilicht in de jaren zeventig groeit het areaal met belichting en de gemiddelde intensiteit van de belichting. Verwacht wordt dat beide in de toekomst blijven toenemen. Voor 2030 wordt verwacht dat circa de helft van het glastuinbouwareaal zich bevindt op vestigingen met belichting (Van der Velden et al., 2018).

Bij de introductie van groeilicht werd de benodigde elektriciteit volledig ingekocht. Later zijn er vanuit efficiëntieoverwegingen (kosten en milieu) op grote schaal wkk's ingezet. Met deze wkk's voorzien glastuinbouwbedrijven zich van elektriciteit, warmte en ook $\mathrm{CO}_{2}$.

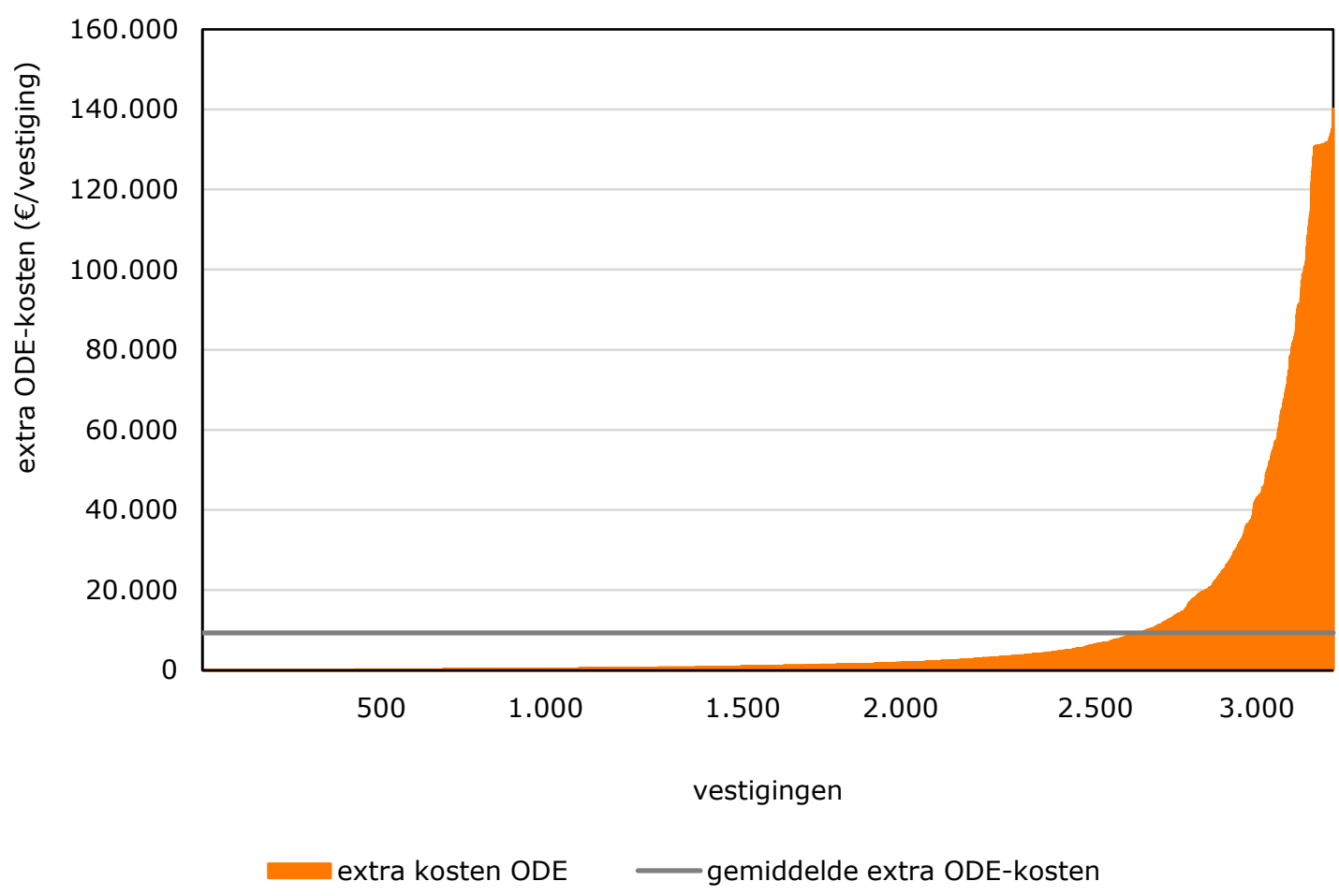

Figuur 2.1 Extra ODE-kosten elektriciteit in 2020 per vestiging in oplopende volgorde

De meeste vestigingen met belichting produceren in de huidige situatie een belangrijk deel van de elektriciteitsbehoefte zelf met wkk's op aardgas, maar niet volledig. Er wordt elektriciteit ingekocht omdat de elektriciteitsproductie met wkk's wordt beperkt door grenzen aan de warmtebenutting uit de wkk en de lampen, ofwel door de warmtevraag van het bedrijf. 
Vestigingen met belichting en zonder wkk kopen alle benodigde elektriciteit in. Dit laatste komt minder voor dan vestigingen met eigen productie (groep 3 in tabel 2.1). Vestigingen met belichting en zonder wkk hebben een kleinere bedrijfsomvang ( $\left.\mathrm{m}^{2} \mathrm{kas}\right)$, de intensiteit van de belichting $\left(\mathrm{W} / \mathrm{m}^{2}\right)$ en/of de gebruiksduur van de belichting (uur/jaar) zijn minder groot, ofwel er wordt minder intensief belicht. Hierdoor is de elektriciteitsvraag kleiner en is een wkk vaak niet rendabel. Er zijn ook grote vestigingen zonder wkk met belichting. Deze groep koopt vaak elektriciteit in en voorziet in de warmtevraag door een energievoorziening zonder $\mathrm{CO}_{2}$-emissie zoals duurzame energie en inkoop warmte van derden. Dit komt verder aan bod in paragraaf 2.5.

\subsubsection{Groepen vestigingen}

In de figuren 2.2 en 2.3 zijn de extra kosten door de ODE-wijziging in 2020 weergegeven voor de vestigingen zonder belichting en zonder wkk en voor zonder belichting en met wkk. In de figuren 2.4 en 2.5 is dat gedaan voor de vestigingen met belichting en zonder wkk en met belichting en met wkk. In de figuren is een horizontale lijn getrokken op het niveau van de gemiddelde extra ODE-kosten van de betreffende groep.

In tabel 2.1 is voor deze groepen kwantitatieve informatie vermeld over de structuur, de inkoop van elektriciteit en de extra OD- kosten. Uit de structuurkenmerken blijkt dat twee derde van de vestigingen behoort tot de groep zonder belichting en zonder wkk. Het areaal van deze groep 1 beslaat echter maar een derde van het totaal areaal. De gemiddelde omvang van deze vestigingen is met 1,4 ha circa de helft van de gemiddelde omvang in de totale glastuinbouw. Bij groep 4, met belichting en met wkk is het tegenovergestelde het geval. Deze groep omvat met $15 \%$ van de vestigingen $34 \%$ van het totaal areaal. De gemiddelde omvang van deze vestigingen is met 6,4 ha ruim tweemaal zo groot als de gemiddelde omvang (2,8 ha).

In groep 2 (zonder belichting en met wkk) bevindt zich $11 \%$ van de vestigingen en $27 \%$ van het totaal areaal en in groep 3 (met belichting en zonder wkk) 7\% van de vestigingen en $7 \%$ van het totaal areaal.

De vestigingen met belichting (groepen 3 en 4) omvatten circa 40\% van het areaal en nemen in 2018 circa $50 \%$ van de $\mathrm{CO}_{2}$-emissie van de glastuinbouw voor hun rekening. $\mathrm{Bij}$ de vestigingen met belichting ligt de $\mathrm{CO}_{2}$-uitstoot per $\mathrm{m}^{2}$ dus hoger. Dit komt niet alleen door het gebruik van aardgaswkk's, ook de warmtevraag van de gewassen met belichting ligt op een hoger niveau.

\section{Vestigingen zonder belichting}

De groep vestigingen zonder belichting is onderverdeeld in een subgroep zonder wkk en een subgroep met wkk. Uit figuur 2.2 blijkt dat de extra ODE-kosten voor de vestigingen zonder wkk in 2020 gemiddeld $€ 1.000$ ( $+81 \%)$ bedragen, uiteenlopend van nihil tot ruim $€ 31.000(+167 \%)$. De relatief lage extra kosten komen doordat er in deze groep vestigingen zijn zonder of met een heel beperkte hoeveelheid inkoop van elektriciteit. Dit zijn zeer kleine energie-extensieve vestigingen. De hoogste extra kosten in deze groep treden op bij de vestigingen met het grootste areaal kassen.

De vestigingen in deze groep met een kostenstijging boven het gemiddelde in deze groep ( $€$ 1.000) vertegenwoordigen $28 \%$ van de vestingen met daarop $69 \%$ van het areaal in deze groep. De kostenstijging voor deze vestigingen is gemiddeld $€ 2.800$ en omvat $78 \%$ van de totale kostenstijging in deze groep.

Uit figuur 2.3 blijkt dat de extra ODE-kosten voor de vestigingen zonder belichting en met wkk in 2020 gemiddeld $€ 4.400$ ( $+127 \%)$ bedragen en uiteenlopen van bijna nihil tot bijna $€ 38.000$ ( $+169 \%)$. De verschillen komen door de dezelfde oorzaken als bij de groep zonder belichting en zonder wkk. Bij de groep met wkk zijn de vestingen relatief groter waardoor de absolute extra kosten absoluut hoger zijn.

De vestigingen in deze groep met een kostenstijging boven het gemiddelde in deze groep ( $€$ 4.400) vertegenwoordigen 33\% van de vestingen met daarop 64\% van het areaal in deze groep. De kostenstijging voor deze vestigingen is gemiddeld $€ 9.000$ en omvat $68 \%$ van de totale kostenstijging in deze groep. 


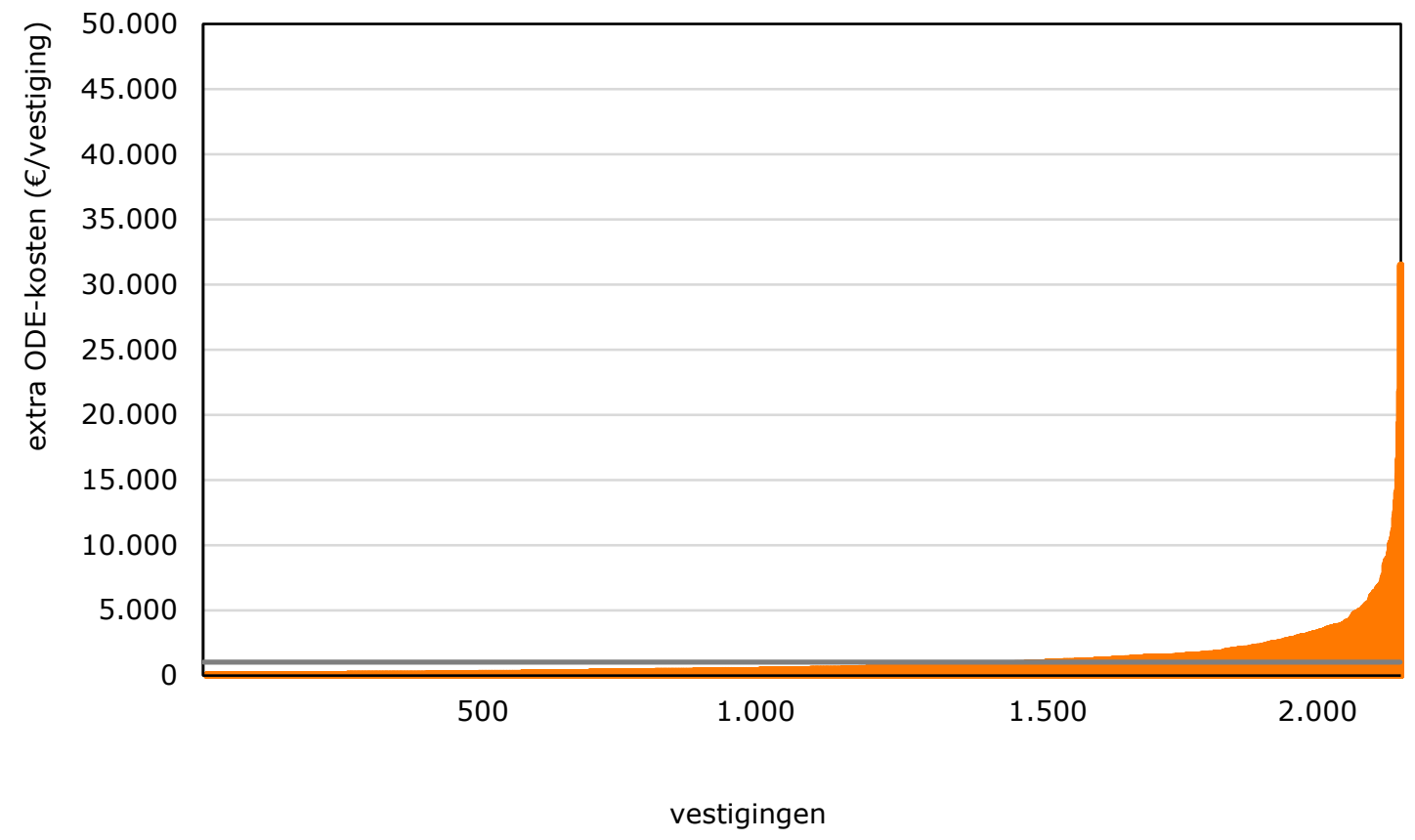

extra kosten ODE

- gemiddelde extra ODE-kosten

Figuur 2.2 Extra ODE-kosten elektriciteit in 2020 per vestiging voor de subgroep vestigingen zonder belichting en zonder wkk in oplopende volgorde

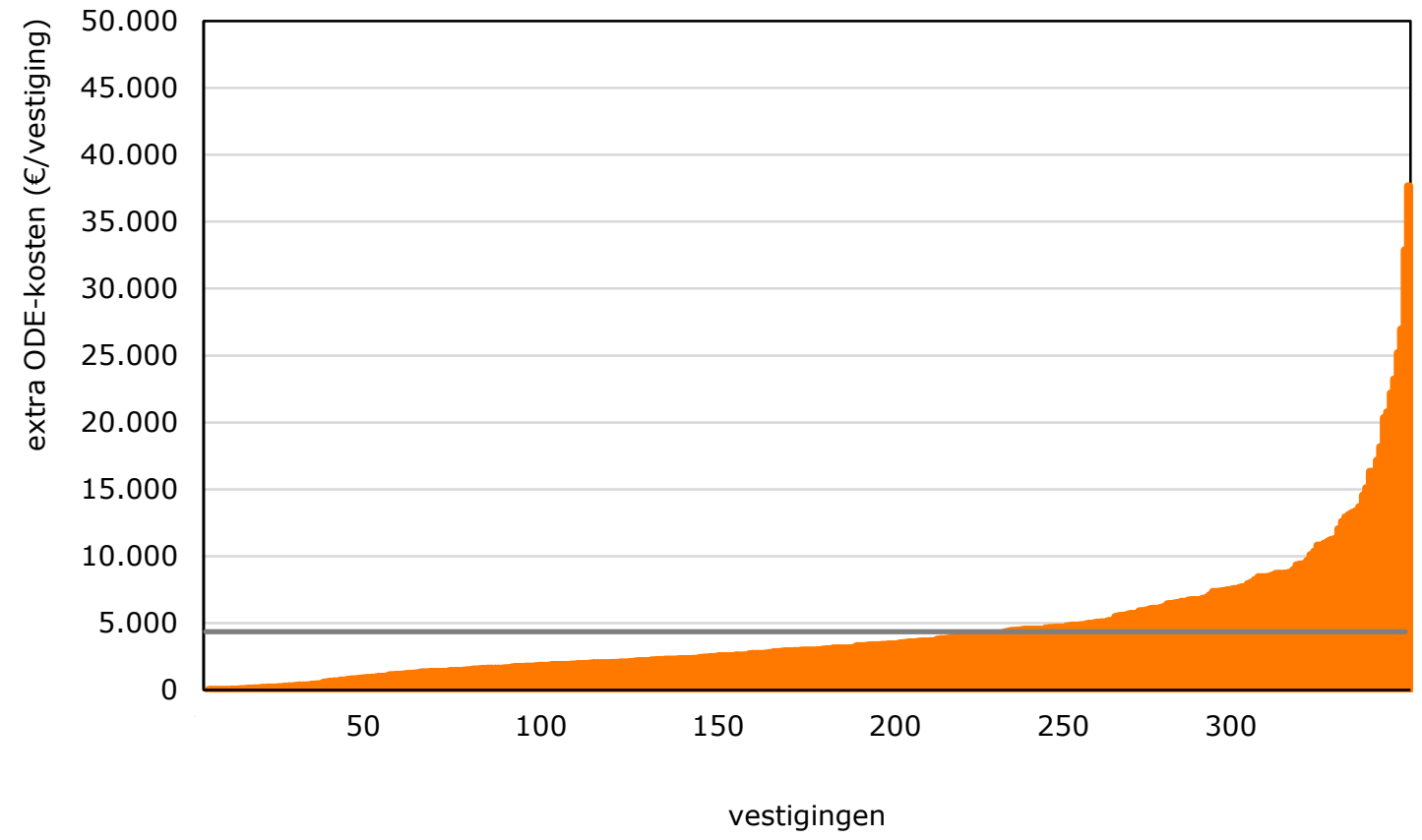

extra kosten ODE

— gemiddelde extra ODE-kosten

Figuur 2.3 Extra ODE-kosten elektriciteit in 2020 per vestigingen voor de subgroep vestigingen zonder belichting met wkk in oplopende volgorde 


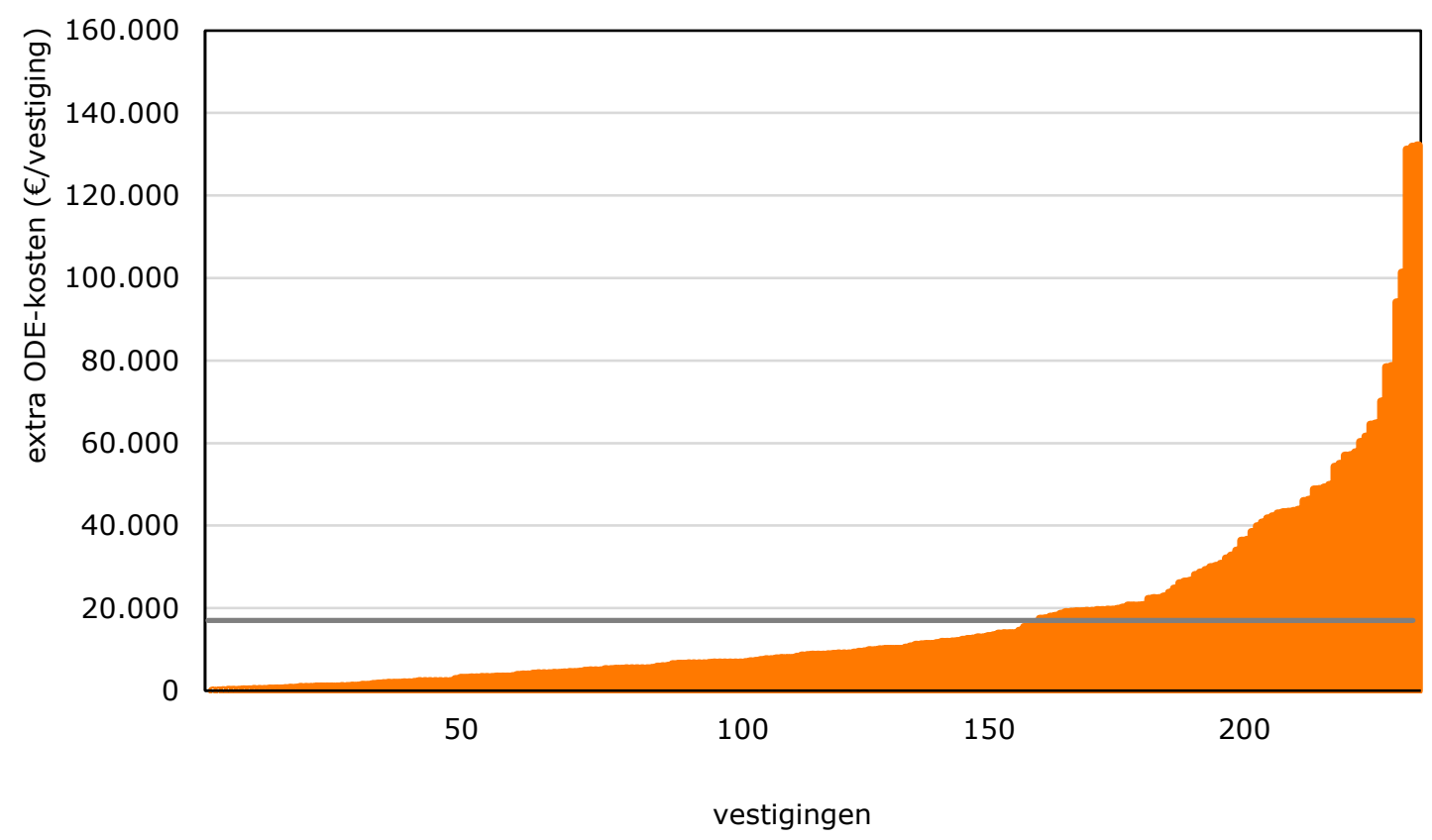

extra kosten ODE

- gemiddelde extra ODE-kosten

Figuur 2.4 Extra ODE-kosten elektriciteit in 2020 per vestiging voor de subgroep met vestigingen met belichting zonder wkk in oplopende volgorde

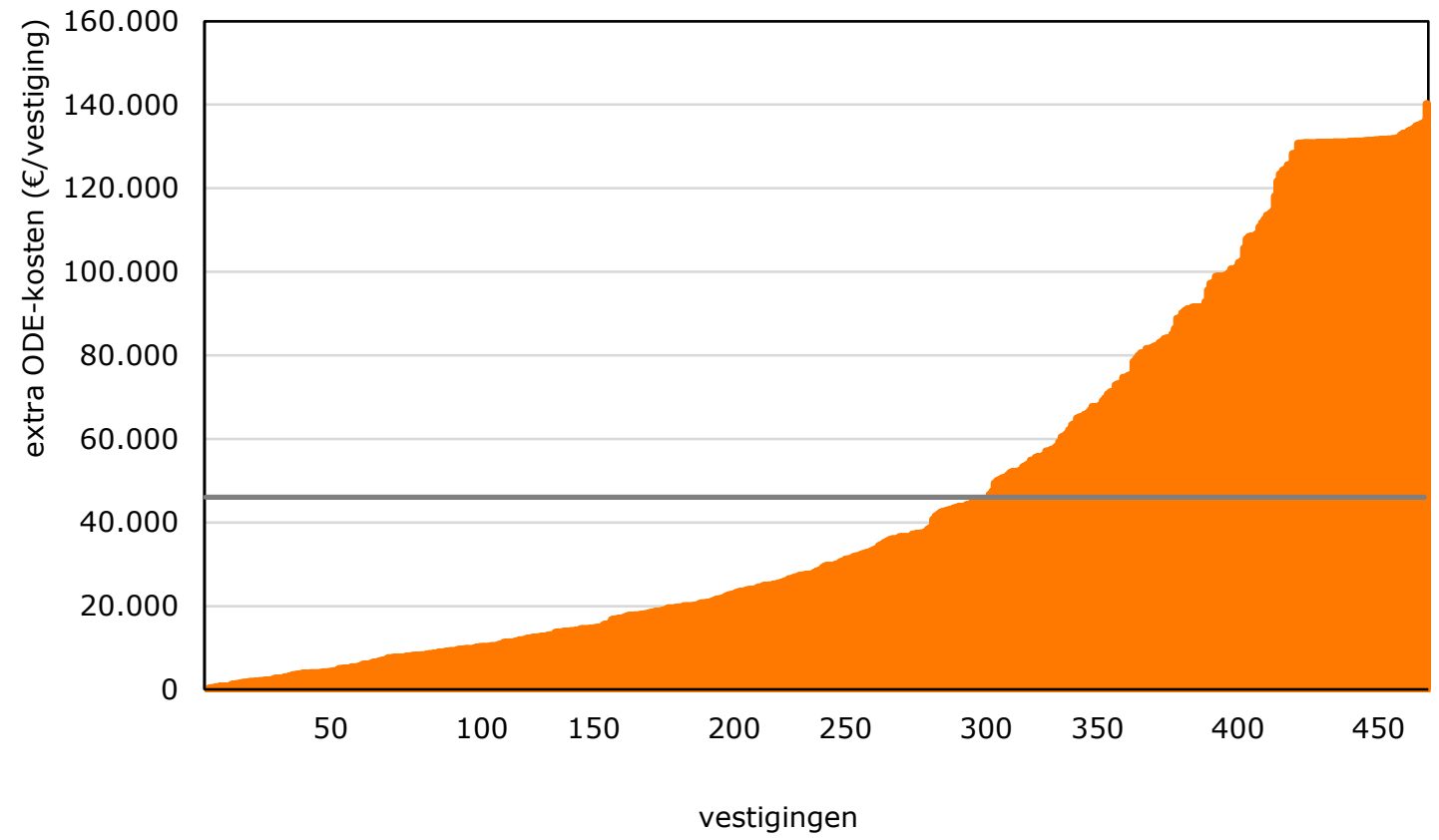

extra kosten ODE $\quad$ gemiddelde extra ODE-kosten

Figuur 2.5 Extra ODE-kosten elektriciteit in 2020 per vestiging voor de subgroep met vestigingen met belichting met wkk in oplopende volgorde

Alle vestigingen zonder belichting

Voor alle vestigingen zonder belichting (groep 1 en 2 samen) bedragen de extra kosten in 2020 gemiddeld $€ 1.500$ ( $+95 \%$ ) per vestiging en deze lopen uiteen van bijna nihil tot bijna $€ 29.000$ 
$(+166 \%)^{4}$ (tabel 2.1). Binnen deze groep heeft $2 \%$ van de vestigingen met daarop $20 \%$ van het areaal extra ODE-kosten die boven het gemiddelde van de sector liggen ( $€$ 9.300). Voor 2025 is de gemiddelde kostenstijging voor de vestigingen zonder belichting ten opzichte van 2019 berekend op $€ 2.500$ ( $+159 \%)$. Deze kostenstijging is circa tweederde hoger dan de kostenstijging in 2020.

\section{Vestigingen met belichting}

De groep vestigingen met belichting is ook onderverdeeld in een subgroep zonder wkk en een subgroep met wkk. Uit figuur 2.4 blijkt dat de extra ODE-kosten voor de vestigingen met belichting en zonder wkk in 2020 gemiddeld $€ 17.000(+160 \%)$ bedragen en uiteenlopen van minder dan $€ 100$ tot ruim $€ 132.000$ ( $+174 \%)$. Deze groep wordt gekenmerkt door een bedrijfsomvang die net onder het gemiddelde in de sector zit en door gemiddeld minder intensieve belichting. De hoogste extra kosten in deze groep behoren bij de vestingen met het grootste areaal kassen. De vestigingen in deze groep met een kostenstijging boven het gemiddelde in deze groep ( $€$ 17.000) vertegenwoordigen $32 \%$ van de vestingen met daarop $63 \%$ van het areaal in deze groep. De kostenstijging voor deze vestigingen is gemiddeld $€ 41.000$ en omvat $76 \%$ van de totale kostenstijging in deze groep.

Uit figuur 2.5 blijkt dat de extra ODE-kosten voor de vestigingen met belichting en wkk in 2020 gemiddeld $€ 46.000$ ( $+168 \%$ ) bedragen. De extra kosten lopen uiteen van bijna nihil tot boven de $€ 140.000$ ( $+175 \%)$. Deze groep wordt gekenmerkt door een relatief grote bedrijfsomvang en intensievere belichting (meer lampen per eenheid areaal). De verschillen in kosten in deze groep komen doordat er gewassen zijn met een kleine en een grote belichtingsintensiteit per $\mathrm{m}^{2}$ en door de verschillen in omvang van de vestigingen $\left(\mathrm{m}^{2}\right)$. De vestingen met de meest intensieve belichting en het grootste areaal kassen ondervinden de hoogste extra kosten in deze groep.

De extra ODE-kosten vlakken in de rechterkant van de figuur af. Dit komt doordat bij deze vestigingen het laatste deel van de inkoop van elektriciteit in de vierde staffel van de ODE zit. De tarieven en de toename van de ODE-tarieven in de vierde staffel zijn relatief klein in vergelijking met de derde staffel, waar het zwaartepunt van deze groep zit. De afvlakking geldt voor circa $10 \%$ van de 475 vestigingen in deze groep.

In deze groep zijn er beduidend meer vestigingen met relatief hoge kosten ( $€ 100.000)$ dan in de groepen 1, 2 en 3. Dit komt door de grotere omvang in combinatie met de hogere belichtingsintensiteit van de vestigingen in deze groep waardoor er meer elektriciteit wordt ingekocht. De vestigingen in deze groep met een kostenstijging boven het gemiddelde in deze groep ( $€$ 46.000) vertegenwoordigen $36 \%$ van de vestigingen met daarop $58 \%$ van het areaal in deze groep. De kostenstijging voor deze vestigingen is gemiddeld $€ 96.000$ en omvat $75 \%$ van de totale kostenstijging in deze groep.

\section{Alle vestigingen met belichting}

Voor alle vestigingen met belichting (groep 3 en 4 samen) bedragen de extra kosten in 2020 gemiddeld $€ 36.500(+167 \%)$ en deze lopen uiteen van $€ 200$ (+39\%) tot $€ 136.000^{5}$ (+175\%) (tabel 2.1). De gemiddelde extra ODE-kosten zijn voor de vestigingen met belichting daarmee een factor 24 hoger dan bij de vestingen zonder belichting. Binnen de groep met belichting heeft $69 \%$ van de vestigingen met daarop $88 \%$ van het areaal extra ODE-kosten die boven het gemiddelde van de gehele sector liggen ( $€ 51.000$ ten opzichte van $€ 9.300$ ). De vestigingen met belichting met extra kosten onder het gemiddelde zijn relatief klein ( $\left.\mathrm{m}^{2} \mathrm{kas}\right)$ met extensievere belichting. Het grootste deel van het areaal met belichting heeft te maken met een substantiële kostenstijging. In 2025 is de gemiddelde kostenstijging ten opzichte van 2019 becijferd op $€ 55.500$. (+153\%). Deze kostenstijging is ruim $50 \%$ hoger dan de kostenstijging in 2020 .

\section{Samenvattend}

Uit het voorgaande blijkt dat de tariefwijziging van de ODE leidt tot een kostenstijging in de glastuinbouw en dat deze kostenstijging, zowel absoluut als relatief, niet evenredig is verdeeld over

\footnotetext{
4 Deze spreiding wijkt af van de getallen die hiervoor zijn genoemd doordat in tabel 2.1 voor de spreiding is uitgegaan van de 5 vestingen met de laagste en de 5 vestigingen met de hoogste extra kosten.

5 Deze spreiding wijkt af van de getallen die hiervoor zijn genoemd doordat in tabel 2.1 voor de spreiding is uitgegaan van de 5 vestingen met de laagste en de 5 vestigingen met de hoogste extra kosten.
} 
vestigingen. Voor de vestigingen zonder belichting is de kostenstijging kleiner dan voor vestigingen met belichting. De vestigingen met belichting worden geconfronteerd met substantiële kostenstijgingen. Dit geldt zowel voor de vestigingen met wkk als de vestigingen die de benodigde elektriciteit volledig inkopen.

Binnen de gehele glastuinbouwsector heeft $17 \%$ van de vestigingen met daarop $48 \%$ van het areaal in 2020 extra ODE-kosten die boven het gemiddelde van de gehele sector liggen ( $€$ 9.300). Op deze vestigingen zit $€ 25$ miljoen extra ODE-kosten ofwel 87\% van de totale extra ODE-kosten in 2020 . Deze groep vertegenwoordigt circa $50 \%$ van de $\mathrm{CO}_{2}$-emissie van de glastuinbouw in 2018 .

Wordt per subgroep (zonder en met belichting en zonder en met wkk) gekeken dan heeft bij alle subgroepen circa een derde van de vestingen met daarop circa twee derde van het areaal een kostenstijging die boven het gemiddelde per groep ligt. Voor deze vestigingen met een bovengemiddelde kostenstijging ligt bij alle vier de groepen de kostenstijging ruim tweemaal hoger dan het gemiddelde per subgroep.

\subsection{Effecten op kosten, rentabiliteit en bedrijfsresultaat}

Van vestigingen naar gespecialiseerde bedrijven

In de vorige paragraaf zijn de extra ODE-kosten op elektriciteit behandeld per vestiging. De effecten van de extra kosten op de rentabiliteit en het bedrijfsresultaat worden bepaald voor de gespecialiseerde bedrijven c.q. op bedrijfstakniveau. De gespecialiseerde glastuinbouwbedrijven zijn groter en kunnen uit meerdere vestigingen bestaan. Op de vestigingen die behoren tot de gespecialiseerde glastuinbouwbedrijven zijn de extra ODE-kosten daardoor hoger en bedragen gemiddeld $€ 11.500$ per bedrijf en 35 eurocent per $\mathrm{m}^{2}$. Vanuit dit gemiddelde per $\mathrm{m}^{2}$ zijn de gemiddelde kosteneffecten op de gespecialiseerde bedrijven berekend. Dit is gedaan voor alle gespecialiseerde bedrijven en voor de subgroepen zonder en met belichting (tabel 2.2).

\section{Alle bedrijven}

De totale kosten op de gespecialiseerde glastuinbouwbedrijven c.q. bedrijfstakniveau nemen door de tariefwijziging van de ODE daardoor met gemiddeld $0,6 \%$ toe. De toename van de nettoenergiekosten bedraagt $4 \%$. De rentabiliteit neemt met 0,6 procentpunt af. Dit laatste komt overeen met een daling van het gemiddelde nettobedrijfsresultaat (= winst of marge) met $6 \%$. De gemiddelde kostenstijging en de gemiddelde effecten op genoemde kentallen zijn daarmee beperkt van omvang.

In paragraaf 2.2 is al gemeld dat de gemiddelde effecten op kosten een onvolledig inzicht geeft in de effecten op bedrijfsniveau. Dat geldt ook voor de effecten op de rentabiliteit en het bedrijfsresultaat. Hierna wordt daarom ingegaan op de effecten op het bedrijfsresultaat voor bedrijven zonder en met belichting.

\section{Bedrijven zonder belichting}

Kijken we naar deze kentallen voor de gespecialiseerde bedrijven zonder belichting (tabel 2.2), dan blijkt dat de effecten van de ODE-tariefswijziging voor elektriciteit van 2020 bij deze subgroep beduidend kleiner zijn. Bij deze subgroep zijn de gemiddelde kostenstijging en de gemiddelde effecten op genoemde kentallen daarmee ook beperkt van omvang.

\section{Bedrijven met belichting}

Bij de bedrijven met belichting is het tegengestelde het geval. Bij deze subgroep zijn de kostenstijging door de ODE-tariefswijziging voor elektriciteit van 2020 en de effecten op de genoemde kentallen beduidend groter. In de subgroep met belichting liggen de effecten bij de genoemde kentallen een factor 5 tot 10 ongunstiger ten opzichte van de subgroep zonder belichting. Bij de eerste groep daalt het bedrijfsresultaat met circa $2 \%$ en bij de tweede groep met circa $11 \%$. Bij de subgroep met belichting is de gemiddelde kostenstijging en zijn de gemiddelde effecten op genoemde kentallen dus beduidend groter. 
Tabel 2.2 Gemiddelde effecten van de kostenstijging van de ODE elektriciteit op totale kosten, netto-energiekosten, rentabiliteit en nettobedrijfsresultaat op de gespecialiseerde glastuinbouwbedrijven, opgesplitst naar zonder en met belichting, in 2020 a)

\begin{tabular}{|c|c|c|c|c|c|c|c|}
\hline \multirow{3}{*}{$\begin{array}{l}\text { Grootheid } \\
\text { Kosteneffect b) }\end{array}$} & \multirow{3}{*}{$\begin{array}{l}\text { Eenheid } \\
€ / \mathrm{m}^{2}\end{array}$} & \multicolumn{6}{|c|}{ Bedrijven } \\
\hline & & \multicolumn{2}{|c|}{ alle bedrijven } & \multicolumn{2}{|c|}{ zonder belichting } & \multicolumn{2}{|c|}{ met belichting } \\
\hline & & + & 0,35 & + & 0,07 & + & 0,72 \\
\hline Netto-energiekosten c) & $\%$ & + & 4 & + & 1 & + & 7 \\
\hline Rentabiliteit d) & procentpunt & - & 0,6 & - & 0,2 & - & 1,0 \\
\hline
\end{tabular}

a) Referentie bedrijfsresultaten 2018; b) Ten opzichte van 2019; c) Netto-energiekosten is inkoop minus verkoop, en exclusief transport;

d) Rentabiliteit is opbrengsten per $€ 100$ kosten; e) Nettobedrijfsresultaat is opbrengsten minus kosten (betaald en toegerekend)

\section{Gewassen}

In de analyse tot nu toe is geconstateerd dat de grootste effecten van de tariefswijziging op inkoop van elektriciteit op de kosten, de rentabiliteit en bedrijfsresultaat plaatsvinden bij de bedrijven met belichting. Ook daarbinnen zijn er verschillen.

Uit een nadere analyse van de vestigingen die geconfronteerd worden met de grootste absolute kostenstijging blijkt dat dit vooral de vestigingen zijn met belichting bij de gewassen: chrysant, Lisianthus, roos, en tomaat. Het areaal op deze vestigingen omvat in 2018 circa $17 \%$ van het totaal areaal glastuinbouw. Hierbij dient opgemerkt te worden dat niet alle vestigingen met tomaat belichting toepassen en vaak ook maar op een deel van een vestiging.

De extra kosten door de wijziging van de ODE-kosten elektriciteit voor de vestigingen met deze gewassen en met belichting is gerelateerd aan de globale geldopbrengst van de glastuinbouwproducten $\left(€ / \mathrm{m}^{2}\right.$.jaar). Dit aandeel ligt bij chrysant op ruim $1 \%$ van de omzet, bij Lisianthus op bijna 2,5\%, bij roos op bijna $2 \%$ en bij belichte tomaat op bijna $1 \%$. Deze aandelen liggen een factor 1,5 tot 4 hoger dan de gemiddelde kostenstijging in de gehele bedrijfstak $(0,6 \%)$ en liggen ook hoger dan de gemiddelde kostenstijging bij de bedrijven met belichting. Dit betekent dat de mutaties van de totale kosten, de netto-energiekosten, de rentabiliteit en het bedrijfsresultaat bij deze bedrijven ongunstiger zijn in vergelijking met het gemiddelde in de glastuinbouw en met het gemiddelde van de bedrijven met belichting.

\subsection{Voorlopers reductie $\mathrm{CO}_{2}$-emissie}

In de glastuinbouw zijn er enkele vestigingen die geen aardgas meer gebruiken om hun kassen te verwarmen. $\mathrm{Zij}$ stoten hierdoor geen $\mathrm{CO}_{2}$-emissie uit. Deze voorlopers hebben vergaande stappen genomen in energiebesparing en energievoorziening zonder $\mathrm{CO}_{2}$-emissie. Hiervoor is extra elektrische apparatuur in gebruik. De inzet van deze extra apparatuur verhoogt de elektriciteitsvraag en brengt extra inkoop van elektriciteit met zich mee. Hiernaast kopen deze voorlopers ook de elektriciteit in die in de referentiesituatie met de wkk zou worden geproduceerd. De extra inkoop van elektriciteit komt bovenop de referentiewaarden die in de berekeningen eerder in dit hoofdstuk zijn gebruikt.

In tabel 2.3 zijn de kenmerken van vier uiteenlopende voorlopers globaal behandeld. Bij deze vestigingen betreft de extra elektrische apparatuur duurzame energievoorzieningen, elektrische boilers, warmtewisselaars, warmtepompen, warmte-koudeopslag en luchtbehandeling. Bovendien maken alle voorlopers gebruik van externe $\mathrm{CO}_{2}$ voor de groei van het gewas, omdat rookgassen uit de verbranding van aardgas niet beschikbaar komen bij vestigingen zonder $\mathrm{CO}_{2}$-emissie.

De extra inkoop van elektriciteit ten opzichte van de referentiesituatie is per voorloper globaal gekwantificeerd en hiermee zijn de extra ODE-kosten berekend. De extra OD-kosten zijn weergegeven in figuur 2.6. Figuur 2.6 komt overeen met figuur 2.1, maar met daaraan toegevoegd de extra ODEkosten van de vier voorlopers. De extra ODE-kosten van drie van de vier voorlopers blijken 
substantieel hoger. De extra ODE-kosten liggen voor hen gemiddeld circa $350 \%$ hoger dan in de referentiesituatie. Hierop is voorloper 1 (rechtsboven in de figuur) een uitzondeling. Voor deze voorloper zijn de extra ODE-kosten in de referentiesituatie al hoog waarbij het laatste deel van elektriciteitsgebruik in de vierde staffel ( $>10$ miljoen $\mathrm{kWh}$ ) van de ODE-tarieven viel. De toename van de ODE-tarieven in de vierde staffel is kleiner dan die in de derde staffel. Gemiddeld voor alle vier de voorlopers liggen de extra ODE kosten in 2020 ten opzichte van 2019 262\% hoger dan in de referentiesituatie.

Uit het voorgaande blijkt dat bij vergaande en volledige reductie van de $\mathrm{CO}_{2}$-emissie de extra ODEkosten voor elektriciteit bij de meeste vestigingen substantieel hoger liggen.

Tabel 2.3 Kenmerken van een viertal voorlopende glastuinbouwbedrijven zonder $\mathrm{CO}_{2}$-emissie

\begin{tabular}{ll} 
& Teelt en overige kenmerken \\
1 & $\begin{array}{l}\text { Planten met belichting, } \\
\text { teeltconditionering, warmtepomp, warmte-koudeopslag, elektrische boiler, } \mathrm{HDN} \text {-lampen, externe } \mathrm{CO}_{2}\end{array}$ \\
\hline $2 \quad \begin{array}{l}\text { Bloemen met belichting, } \\
\text { teeltconditionering, warmtepomp, warmte-koudeopslag, ledlicht, verbinding cluster, externe } \mathrm{CO}_{2}\end{array}$ \\
$\begin{array}{l}\text { Groente zonder belichting, } \\
\text { aardwarmte, inkoop warmte van derden, externe } \mathrm{CO}_{2}\end{array}$ \\
$\begin{array}{l}\text { Perkgoed zonder belichting, } \\
\text { biobrandstof, externe } \mathrm{CO}_{2}\end{array}$ \\
\hline
\end{tabular}

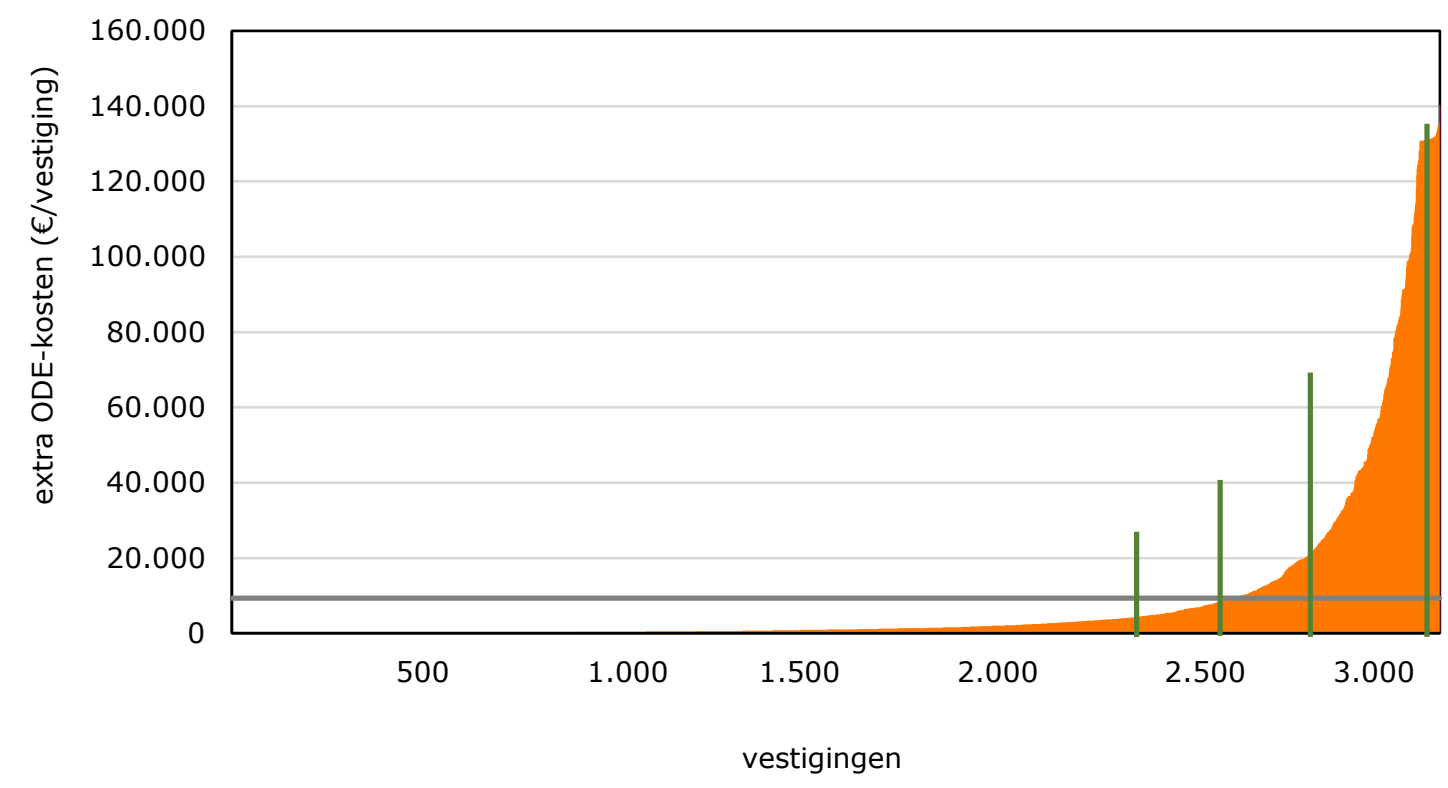

\footnotetext{
alle vestigingen, exclusief voorlopers zonder $\mathrm{CO}_{2}$-emissie

voorlopers zonder $\mathrm{CO}_{2}$-emissie

- gemiddelde extra ODE-kosten
}

Figuur 2.6 Extra ODE-kosten elektriciteit in 2020 per vestiging in oplopende volgorde met daarin de extra kosten van 4 bestaande voorlopers zonder $\mathrm{CO}_{2}$-emissie 


\section{Effecten $\mathrm{CO}_{2}$-emissie}

\section{$3.1 \quad$ Inleiding}

Het energiegebruik in de glastuinbouw is in transitie. Al lange tijd werken tuinders, overheden en hun partners aan het verlagen van de $\mathrm{CO}_{2}$-emissie. De verhoging van de elektriciteitskosten door de wijziging van de ODE-tarieven elektriciteit heeft impact op diverse aspecten die gericht zijn op het verlagen van de $\mathrm{CO}_{2}$-emissie.

In dit hoofdstuk worden de partiële effecten van de wijziging van de ODE-tarieven op de ontwikkeling van de $\mathrm{CO}_{2}$-emissie behandeld. Hierbij is eerst de huidige energiesituatie en de $\mathrm{CO}_{2}$-emissie van de glastuinbouw (2018) beschreven. Vervolgens komen de prognoses van de $\mathrm{CO}_{2}$-emissie 2030 en het transitiepad naar 2030 aan bod. Ten slotte wordt de het handelen van glastuinbouwondernemers als reactie op de kostenverhoging van de ODE en bijhorende effecten op de $\mathrm{CO}_{2}$-emissie uiteengezet.

In hoofdstuk 2 is gebleken dat door de wijzing van de ODE-tarieven elektriciteit vooral de glastuinbouwvestigingen met belichting geconfronteerd worden met een substantiële kostenstijging. Hierbij is de elektriciteitsproductie met aardgas-wkk's belangrijk. Deze productie wordt deels door de vestigingen zelf toegepast en deels verkocht. Inzet van wkk gericht op verkoop vindt voor het overgrote deel plaats door de grotere vestigingen zonder belichting. De ODE op inkoop van elektriciteit heeft daar geen invloed op. Verkoop van elektriciteit door vestigingen met belichting vindt ook plaats, maar dan vooral in en rond de zomerperiode. In en rond de winterperiode wordt de geproduceerde elektriciteit vooral gebruikt voor de belichting. Van de totale verkoop elektriciteit op sectorniveau wordt circa $70 \%$ geproduceerd door vestigingen zonder belichting en de resterende $30 \%$ door vestigingen met belichting.

\subsection{Huidige situatie}

In de huidige situatie (2018) wordt de energievraag van de glastuinbouw voor een groot deel gedekt door aardgas (3,2 miljard $\left.\mathrm{m}^{3}\right)$. Het gebruik van duurzame energie (7\%) en inkoop warmte $(3 \%)$ is groeiende maar beperkt van omvang. Het aardgasverbruik leidt tot $\mathrm{CO}_{2}$-emissie van de glastuinbouw. Het aardgas wordt gebruikt in wkk's en ketels. Op sectorniveau wordt $80-85 \%$ van het aardgas gebruikt in wkk's. Met aardgas-wkk's wordt met nuttig gebruik van de geproduceerde warmte (Smit en van der Velden, 2008) elektriciteit geproduceerd voor eigen consumptie en voor de verkoop. Aanvullend op de eigen productie wordt elektriciteit ingekocht (circa $40 \%$ van het verbruik).

Door de glastuinbouwsector werd in 2018 2,8 miljard kWh elektriciteit ingekocht. Daarnaast werd er 9,4 miljard kWh geproduceerd met aardgas-wkk's. Daarvan werd 5,6 miljard kWh verkocht en 3,8 miljard kWh geconsumeerd. Hieruit volgt een totale elektriciteitsconsumptie door de glastuinbouw van 6,6 miljard kWh. Deze consumptie werd voor ruim $80 \%$ gebruikt voor belichting en het resterende deel voor overige elektrische apparatuur.

\subsection{Prognoses 2030}

Het is gewenst dat de $\mathrm{CO}_{2}$-emissie van de glastuinbouw wordt gereduceerd. WEcR heeft in 2018 een prognose gemaakt van de $\mathrm{CO}_{2}$-emissie van de glastuinbouw in 2030 (Van der Velden et al., 2018). Hiervoor zijn drie scenario's ontwikkeld. De scenario's onderscheidden zich vooral in economische groei (pessimistisch, gematigd en optimistisch). De verschillen tussen de scenario's zaten in het totaal areaal glastuinbouw, het areaal met belichting, het areaal met aardgas-wkk's, de hoeveelheid 
duurzame warmte en de hoeveelheid warmte die van derden wordt afgenomen. Op hoofdlijnen is in alle drie de scenario's uitgegaan van het volgende.

- Het gebruik van aardgas-wkk's door bedrijven zonder belichting valt vrijwel weg.

- Het areaal met belichting en het areaal op bedrijven met belichting nemen toe.

- De intensiteit van de belichting (hoeveelheid licht $/ \mathrm{m}^{2}$ ) neemt toe.

- Aardgas-wkk's blijven door bedrijven met belichting ingezet worden, maar in combinatie met reductie van de warmtevraag is het vermogen van de wkk's per $\mathrm{m}^{2}$ is minder groot. ${ }^{6}$

- Het gebruik van overige elektrische apparatuur neemt verder toe. ${ }^{7}$

\subsection{Transitiepad naar 2030}

Uit de informatie uit de voorgaande paragrafen volgt een transitiepad voor de $\mathrm{CO}_{2}$-emissie van de glastuinbouw voor de periode naar 2030. Dit transitiepad omvat onder meer:

- Door het uit gebruik nemen van wkk's op het areaal zonder belichting wordt substantieel minder elektriciteit verkocht.

- De elektriciteitsconsumptie voor belichting neemt toe (areaal en intensiteit).

- De elektriciteitsvoorziening verschuift van eigen productie met aardgas-wkk's naar inkoop.

- De absolute hoeveelheid inkoop van elektriciteit neemt in alle drie de scenario's toe.

- De toepassing van duurzame warmte en de aankoop van warmte van derden neemt substantieel toe ter vervanging van aardgas-wkk's.

De activiteiten van het programma Kas als Energiebron dragen bij aan deze ontwikkelingen.

\section{Gezamenlijke ontwikkeling}

In het transitiepad treedt een verschuiving op van aardgas-wkk's naar inkoop van elektriciteit in combinatie met het gebruik van duurzame energie, inkoop warmte en externe $\mathrm{CO}_{2}$. Hierdoor daalt de $\mathrm{CO}_{2}$-emissie van de glastuinbouw substantieel. Voor deze reductie is het vervangen van de inzet van aardgas-wkk's essentieel. Om dit te realiseren is de ontwikkeling van energievoorzieningen zonder $\mathrm{CO}_{2}$-emissie, zoals inkoop van elektriciteit en warmte en het gebruik van duurzame energie, in combinatie externe $\mathrm{CO}_{2}$-voorziening voor de groei van de gewassen noodzakelijk. Voor de ontwikkeling hiervan wordt al jaren met partijen buiten de glastuinbouw samengewerkt en in toenemende mate. Dit is noodzakelijk, niet alleen voor de benodigde infrastructuur, maar ook omdat bij de energietransitie gezamenlijke kennis en kapitaal nodig zijn en uitdagingen met zich meebrengen die sector overstijgend zijn. Energievoorzieningen zonder $\mathrm{CO}_{2}$-emissie kunnen door tuinbouwondernemers zelf, maar ook met andere partijen samen worden geëxploiteerd. Ook door de relatief grote investeringen in dergelijke projecten, regelgeving, doorlooptijd en projectrisico's is samenwerking met externe partners voor de energietransitie van de glastuinbouw van groot belang. Voorbeelden van partners zijn energiebedrijven, industrie, afval- en zuiveringsbedrijven en projectontwikkelaars.

\subsection{ODE-stijging}

\subsubsection{Reactie op kostenstijging}

\section{Effecten kostenstijging inkoop elektriciteit}

De bedrijven met belichting ondervinden de grootste kostenstijging door de ODE-wijziging op inkoop van elektriciteit (hoofdstuk 2). Voor bedrijven zonder belichting is er een beperktere kostenstijging. Bij de vestigingen met een groot areaal kassen kan dit laatste ook leiden tot een relevante kostenstijging,

\footnotetext{
6 Voor het gebruik van wkk's op de bedrijven met belichting is verondersteld dat de wkk's per $\mathrm{m}^{2}$ kas kleiner zijn door besparing op de warmtevraag door onder andere 'Het Nieuwe Telen'. Door de lagere warmtevraag wordt de warmtebenutting uit de wkk's verder begrensd en hierdoor neemt de inzet van wkk's af door een kleiner vermogen per $\mathrm{m}^{2}$ kas.

7 Het elektriciteitsgebruik van de overige elektrische apparatuur blijft ondanks de groei van de inzet van stabiel $\left(\mathrm{kWh} / \mathrm{m}^{2}\right)$. Dit komt door schaalvergroting in combinatie met het gebruik van efficiëntere apparatuur.
} 
maar op bedrijven met belichting is de kostenstijging substantieel groter. Reactie op de kostenstijging is dus vooral relevant voor de bedrijven met belichting.

Meest voor de hand liggende opties

In bijlage 3 is een overzicht gegeven van de mogelijke handelingsopties door glastuinbouwbedrijven met belichting. Hierbij is onderscheid gemaakt naar de korte termijn (1-2 jaar) en de middellange termijn (2-5 jaar). De meest voor de hand liggende opties worden hieronder behandeld.

\section{Korte termijn}

Voor de korte termijn zijn voor de bedrijven met belichting onderstaande twee opties de meest voor de hand liggende:

1. Intensivering van het gebruik van wkk

Door bestaande wkk's meer te gebruiken, is er minder inkoop van elektriciteit nodig en dat drukt de extra ODE-kosten. De extra inzet wordt op de bedrijven met belichting echter begrensd door de mogelijkheden om de met de wkk geproduceerde warmte te benutten of aan buren te verkopen. Hierdoor biedt het extra gebruik aardgas-wkk's op bedrijven met belichting beperkte mogelijkheden. Dit wordt verderop nader toegelicht.

2. Extensivering van het gebruik van groeilicht

Het extensiveren van de bestaande belichting betekent dat er minder belicht wordt. In bepaalde periode kan de intensiteit en/of de gebruiksduur worden beperkt. De afwegingen hierbij zullen plaatsvinden in nauwe afstemming met de marktverwachtingen van de ondernemer. De belichtingsinzet met de laagste meerwaarde verwachting zal als eerste worden geschrapt. Deze extensivering van de belichting kan een negatieve impact op de opbrengsten alsook de kwaliteitsen leveringsreputatie van het bedrijf. Door deze verstoringen van de afzetmarkt is extensivering van de belichting geen voor de hand liggende optie.

\section{Warmtebenutting $w k k$ 's}

Uit eerder onderzoek (Smit en van der Velden, 2008) is gebleken dat het produceren van elektriciteit met aardgas-wkk's niet rendabel is zonder substantiële benutting van de geproduceerde warmte. Bij de energieprijzen van 2019 en begin 2020 is dat ook het geval, maar is de benodigde warmtebenutting voor de situatie met elektriciteitsproductie voor eigen gebruik kleiner dan in de jaren daarvoor. Dit hangt samen met prijzen van aardgas, de prijzen van elektriciteit, de netwerkkosten en de heffingen (inclusief ODE).

Hiernaast is het zo dat grootschalige warmtevernietiging buiten de kassen met de bestaande wkk's technisch niet mogelijk is. Een alternatief zou kunnen zijn om de niet benutbare warmte af te voeren via de verwarmingsinstallatie in de kassen. Dit stuit echter op teeltkundige bezwaren. De Nederlandse glastuinbouw wordt voor een groot deel gekenmerkt door productie voor het topsegment van de internationale markt. Hierbij is de kwaliteit van de producten van groot belang. De kwaliteit van de producten wordt medebepaald door het klimaat in de kassen. Afvoer van overtollige warmte via de kassen heeft een negatieve invloed op het gewenste klimaat in de kassen. Hierdoor is het afvoeren van warmte via de verwarmingsinstallatie in de kassen maar beperkt mogelijk.

De praktijk van het energiebeheer op bedrijven met belichting was in de situatie voor 2020 deels suboptimaal. De prijzen voor aardgas en inkoop van elektriciteit waren van dien aard dat wkk's zo veel mogelijk ingezet werden en er werd geteeld op het randje van wat warmte- en teelttechnisch mogelijk was. Deze grens is gewas-afhankelijk. Het voorgaande wordt bevestigd door een analyse in de Energiemonitor Glastuinbouw (Van der Velden en Smit, 2019b). Uit deze analyse bleek dat de maandelijkse verkoop van elektriciteit in bepaalde maanden hoger en in bepaalde maanden lager was dan in het jaar ervoor. Verschillen bleken samen te hangen met de buitentemperatuur ofwel de warmtevraag in de kassen. Hieruit blijkt dat de inzet van wkk's begrensd wordt door de warmtevraag van het bedrijf.

\section{Middellange termijn}

Voor de middellange termijn (2-5 jaar) resteren drie voor de hand liggende mogelijkheden:

1. Aanschaf extra nieuwe $w k k$ 's

Ook het in gebruik nemen van extra nieuwe wkk's op aardgas wordt begrensd door de 
mogelijkheden om de met de wkk geproduceerde warmte te benutten. Hierin zit ten opzichte van het korte termijn perspectief wat ruimte als er warmte via een fysieke koppeling aan een andere nabijgelegen (glastuinbouw-)bedrijven kan worden geleverd.

2. Eigen productie duurzame elektriciteit

Bij eigen productie van duurzame elektriciteit is het onderscheid relevant naar wkk's die gebruik maken van biobrandstof en opties die alleen elektriciteit produceren. Voor wkk's op biobrandstof gelden dezelfde beperkingen als voor aardgas-wkk's. Voor productie van alleen elektriciteit zijn zonnepanelen en windmolens de mogelijkheden. Zowel voor bio-wkk's als zon PV en windenergie zijn bestuurlijke en organisatorische aspecten relevant (vergunningen, maatschappelijke weerstrand, aanschaf, installeren, enzovoort) die doorlooptijd vragen. Bovendien dient er fysieke ruimte en bestemmingsruimte te zijn bij het glastuinbouwbedrijf. Ook brengt een windmolen slagschaduw met zich mee. De productie van elektriciteit met zon PV en wind vindt plaats in perioden met zon en/of wind. Zonne elektriciteit is voorhanden als het licht is, en dus overdag. De belichting van tuinbouwgewassen vindt vooral plaats als het daglicht te beperkt is qua intensiteit en daglengte (de periode van en rond de winter). In deze periode is vanwege die beperkte of geen instraling ook weinig productie van zonne-elektriciteit mogelijk. Hiernaast is er naast de kassen weinig plaats op de percelen om zonnepanelen te plaatsen. Windenergie kan zowel overdag als 's nachts beschikbaar zijn, maar er zijn zowel overdag als 's nachts perioden zonder wind waardoor inkoop nodig blijft.

3. Elektriciteitsbesparing

Naast extensivering van de inzet van de belichting kan het elektriciteitsgebruik door belichting worden verminderd door elektriciteitsbesparing. Dit kan door gangbare HDN-armaturen te vervangen door ledlicht en door selectiever belichten.

Ledlicht is een optie die niet gericht is op de energievoorziening, maar op de energievraag. Hierdoor kan de consumptie van elektriciteit verminderen. Door traditionele Hoge Druk Natriumlampen te vervangen door ledlicht kan een glastuinbouwbedrijf de elektriciteitsconsumptie met meer dan een derde reduceren. Hierdoor kan dezelfde hoeveelheid licht met minder elektriciteit gerealiseerd worden of kan met dezelfde eigen opwekking en inkoop van elektriciteit meer licht worden ingezet.

Bij het eerste is het dan de keuze of dit minder eigen opwekking of minder inkoop wordt. Ook ontstaat er ruimte bij de warmtebenutting uit de wkk en de inkoop van elektriciteit brengt meer kosten met zich mee waardoor de inkoop van elektriciteit zal dalen en de eigen opwekking met wkk in stand blijft.

Door de marktvraag naar glastuinbouwproducten in de winterperiode met een bijbehorend hogere opbrengstprijs zal in de praktijk door bedrijven ledlicht vooral worden benut voor intensivering van de belichtingscapaciteit ( $\square \mathrm{mol} / \mathrm{m} 2$.jaar), ofwel meer kunstlicht worden gebruikt met dezelfde hoeveelheid elektriciteitsinput. Dit vindt in de praktijk vooral plaats door een combinatie van leden HDN-lampen (hybridebelichting). Rond het gebruik van ledlicht zijn er belangrijke teeltkundige vragen te beantwoorden, onder andere het aspect stralingswarmte. Hiernaast zijn investeringen in ledlicht substantieel hoger dan in HDN-belichting.

Selectiever belichten zou bij kunnen dragen aan het verminderen van de elektriciteitsbehoefte door niet te belichten tijdens perioden waarin het opbrengst verhogende effect van belichting afwezig of heel beperkt is. Hierover bestaan nog veel teeltkundige en marktkundige vragen waardoor de toepassing in de praktijk momenteel ongewis is.

\section{Samenvattend}

Uit de analyse blijkt dat er zowel voor de korte en voor de middellange termijn slechts beperkt mogelijkheden zijn om de extra kosten deels te reduceren. Extra gebruik van bestaande wkk's of investeren in extra wkk's wordt beperkt door de mogelijkheden om de geproduceerde warmte te benutten. Het produceren van duurzame elektriciteit voor de belichting heeft meer beperkingen dan mogelijkheden en wordt ook momenteel bijna niet gedaan. Door het gebruik van ledlicht zal waarschijnlijk eerder intensivering van de belichting optreden dan dat er minder elektriciteit wordt ingekocht. Rond het gebruik van ledlicht en selectiever belichten voor het realiseren van besparing op 
de elektriciteitsconsumptie bestaan teeltkundige vragen. Ook brengt ledlicht hoge investeringen met zich mee. Door het voorgaande zullen de acties door de glastuinbouwbedrijven als reactie op de op de toegenomen ODE-kosten in de praktijk op de korte termijn beperkt zijn.

Naast de handelingsopties ter vermindering van het kosteneffect zijn er ook ontwikkelingen die niet plaats zullen vinden omdat deze ontwikkelingen het kosteneffect van de ODE-tarieven versterken. Dit is vooral relevant voor de gewenste reductie van de $\mathrm{CO}_{2}$-emissie door verminderd gebruik van aardgas-wkk's en dit komt aan bod in de volgende paragraaf.

\section{Bedrijven zonder belichting}

De bedrijven zonder belichting hebben te maken met beperkte gemiddelde extra ODE-kosten door de relatief kleine elektriciteitsbehoefte per $\mathrm{m}^{2}$ kas. Bij de grote bedrijven zonder belichting kunnen de extra ODE-kosten wel relevant zijn. Deze bedrijven zouden een relatief kleine wkk per $\mathrm{m}^{2}$ kunnen gebruiken om daarmee deels in de eigen elektriciteitsbehoefte te voorzien. Ook dit is tegengesteld aan de prognose van de $\mathrm{CO}_{2}$-emissie 2030. Daarin werd ervan uitgegaan dat het gebruik van aardgaswkk's door bedrijven zonder belichting vrijwel weg valt. Op de bedrijven zonder belichting is de elektriciteitsvraag per $\mathrm{m}^{2}$ beperkt van omvang waardoor deze optie relevant is voor een beperkt aantal hele grote bedrijven. Per saldo zal het effect van deze kostendrukkende optie voor bedrijven zonder belichting zeer klein zijn.

\subsubsection{Effecten reductie $\mathrm{CO}_{2}$-emissie}

De $\mathrm{CO}_{2}$-emissie van de glastuinbouw wordt beïnvloed door een reeks van factoren. In dit onderzoek worden partieel de effecten van de verhoging van de ODE op elektriciteit in beschouwing genomen. De kostenverhoging heeft vooral impact voor de bedrijven met belichting. Relevante factoren hierbij zijn:

1. het gebruik van aardgas-wkk's,

2. de realisatie van warmtebesparing,

3. het gebruik van energievoorzieningen zonder $\mathrm{CO}_{2}$-emissie en

4. de bedrijfsresultaten en financiële positie bedrijven

\section{Aardgas-wkk's}

In de glastuinbouw wordt door de bedrijven met belichting in de huidige situatie in belangrijke mate in de elektriciteitsvraag voorzien met eigen productie met aardgas- wkk's. Hiernaast wordt een deel van de elektriciteitsbehoefte ingekocht. Door de kostenstijging van inkoop van elektriciteit wordt de eigen productie belangrijker. De bedrijven met belichting kunnen reageren op de kostenstijging door meer zelf te produceren met de bestaande wkk's. Dit is echter beperkt realiseerbaar. Het effect zou zijn dat de $\mathrm{CO}_{2}$-emissie niet zal afnemen, maar beperkt zal toenemen.

Belangrijker is dat door de kostenverhoging de wkk's niet uit gebruik genomen worden. Voor toekomstige reductie van de $\mathrm{CO}_{2}$-emissie is het gewenst dat wkk's juist uit gebruik worden genomen en er ook geen nieuwe installaties in gebruik worden genomen. Door de reactie op de gestegen ODEkosten voor inkoop van elektriciteit zal door de bedrijven met belichting juist het tegengestelde plaatsvinden. Dit geldt ook voor een beperkt aantal grote bedrijven zonder belichting. Ook deze grote bedrijven worden geconfronteerd met een belangrijke kostenstijging van de ODE-kosten. Voor deze bedrijven is het in gebruik een relatief kleine wkk per $\mathrm{m}^{2}$ kas een mogelijkheid om op de toename van de ODE-kosten te reageren.

Het overgrote deel van de aardgas-wkk's in de glastuinbouw zijn in gebruik genomen in de periode 2005-2010 (Van der Velden en Smit, 2019b). Dit betekent dat deze installaties in 2020 zo'n 10-15 jaar oud zijn. Bij deze leeftijd en door het einde van het onderhoudscontract ontstaat de vraag of de installatie wordt gereviseerd of wordt vervangen door een nieuwe installatie. Beide gaan gepaard met investeringen. Een gereviseerde installatie kan weer zo'n 5-10 jaar worden gebruikt. Bij een nieuwe installatie is dit voor circa 15 jaar het geval. Dergelijke investeringen worden dus gedaan voor een langere periode.

Door het voorgaande zal het in gebruik houden van wkk's en het in gebruik nemen van nieuwe installaties leiden tot een langdurige inbeslagname van 'transitieruimte'. Wkk-gebruik die voor 2020 in 
plannen van ondernemers bekeken werd om te vervangen door duurzame warmte en inkoop van warmte in combinatie met inkoop van elektriciteit en externe $\mathrm{CO}_{2}$ zal voor lange termijn weer vastzitten aan warmteproductie met de wkk's.

\section{Warmtebesparing}

In de prognose $\mathrm{CO}_{2}$-emissie 2030 werd voorzien dat door selectiever inzetten van warmte (Het Nieuwe Telen) verdere warmtebesparing zou worden gerealiseerd en dat hierdoor het vermogen van de wkk's per $\mathrm{m}^{2}$ kas op de bedrijven met belichting zou dalen in vergelijking met de huidige situatie. Door de reactie op de kostenstijging van de ODE op elektriciteit zullen de vermogens van de wkk's per $\mathrm{m}^{2}$ kas bij de bedrijven met belichting niet kleiner worden, en mogelijk op termijn zelfs stijgen. Hierdoor komt reductie van de warmtevraag door het selectiever inzetten van warmte en dus energiebesparing, op bedrijven met belichting in de knel en zal minder of niet gerealiseerd worden.

\section{Energievoorzieningen zonder $\mathrm{CO}_{2}$-emissie}

Het in gebruik houden van de wkk's blokkeert de gewenste toename van inkoop van elektriciteit in combinatie met het gebruik van duurzame warmte en/of de inkoop van warmte. Bovendien worden de kosten voor de productie vanuit bestaande en nieuw te realiseren duurzame warmteprojecten (aardwarmte, biobrandstof) hoger, omdat dat gepaard gaat met extra elektriciteitsinkoop. Zie hiervoor ook paragraaf 2.5 over de voorlopers bij de reductie van de $\mathrm{CO}_{2}$-emissie. Ook is het mogelijk dat de voorlopers de gerealiseerde transitie inclusief het gebruik van energievoorzieningen zonder $\mathrm{CO}_{2}-$ emissie gaan terugdraaien.

Het realiseren van energievoorzieningen zonder $\mathrm{CO}_{2}$-emissie zoals het ontsluiten van warmte van derden, het realiseren van benodigde infrastructuur en het tot stand brengen van duurzame energieprojecten is steeds vaker een coproductie van glastuinbouwbedrijven en partners van buiten de sector. Bij de realisatie horen complexe activiteiten van ontwikkeling, financiering en beheer. Omwille van kennistoepassing, draagkracht en risicobeheer past dit vaak beter bij consortia. Het in gebruik houden van aardgas-wkk's op de bedrijven met belichting vermindert de economische mogelijkheden voor warmte van partners c.q. derden en van duurzame energieprojecten. Het afzetpotentieel van warmte vanuit dergelijke projecten wordt minder groot en de waarde van de warmte daalt. Dit vermindert het perspectief van de projecten en daarmee het animo van partners om deel te nemen aan deze projecten die bijdragen aan het verlagen van $\mathrm{CO}_{2}$-emissie.

\section{Bedrijfsresultaten en financiële positie glastuinbouwbedrijven}

De kostenverhoging door de ODE-tarieven heeft invloed op de rentabiliteit en het bedrijfsresultaat van de glastuinbouwbedrijven (hoofdstuk 2). Gemiddeld in de sector zijn deze effecten beperkt van omvang. Voor de bedrijven met belichting die met de hoogste kostenstijging worden geconfronteerd zijn deze effecten beduidend sterker. Dit heeft een negatieve invloed op vooruitzichten en ontwikkeling van deze bedrijven in het algemeen. Ook zullen deze glastuinbouwbedrijven zelf minder kunnen investeren, zo ook in energievoorzieningen zonder $\mathrm{CO}_{2}$-emissie. Deze projecten worden juist gekenmerkt door hoge investeringen.

In relatie tot de mogelijke investeringen is het relevant te melden dat in en na de financiële crisis de investeringen in de glastuinbouw in innovatie en modernisering van kassen en nieuwbouw meer zichtbaar waren bij bedrijven met belichting. Zo wordt er door bedrijven met belichting relatief meer duurzame energie toegepast (Van der Velden en Smit, 2019b) en nemen bij gewassen waarvan het areaal niet krimpt, het areaal belichting en de belichtingsintensiteit toe (Van der Velden et al., 2018).

\section{Effect op reductie $\mathrm{CO}_{2}$-emissie}

Door de hiervoor beschreven negatieve effecten op energiebesparing en het gebruik van energievoorzieningen zonder $\mathrm{CO}_{2}$-emissie bij de bedrijven met belichting vanuit de toename van de ODE-kosten zal de gewenste reductie van de $\mathrm{CO}_{2}$-emissie van glastuinbouw, afgeremd worden. Dit staat haaks op doelen van andere beleidsmaatregelen van de overheid en activiteiten van het Programma Kas als Energiebron die gericht zijn op stimulering en versnelling van de $\mathrm{CO}_{2}$-emisie reductie.

De kwantitatieve effecten op de reductie van de $\mathrm{CO}_{2}$-emissie bestaan uit directe en indirecte effecten. 
De directe effecten leiden tot een groter wkk-gebruik dan de prognose 2030:

a. Bij de bedrijven met belichting zal het vermogen van de wkk's per $m^{2}$ gelijk blijven aan de huidige situatie. In de prognose 2030 is uitgegaan van een daling. In combinatie met het voorgaande valt de veronderstelde warmtebesparing weg.

b. Een beperkt aantal grote bedrijven zonder belichting zal een kleine wkk per $\mathrm{m}^{2}$ kas gebruiken. Hierdoor zal het vermogen van de wkk's bij deze bedrijven niet volledig uit gebruik wordt genomen waar in de prognose 2030 van uit is gegaan.

De indirecte effecten omvatten negatieve effecten op de projecten met energievoorziening zonder $\mathrm{CO}_{2}$-emissie en op de kosten van de productie van duurzame energie en het gebruik van energiebesparende technieken. De negatieve effecten op de projecten met energievoorziening zonder $\mathrm{CO}_{2}$-emissie komen voort uit de verminderde animo bij de benodigde samenwerkingspartners en geldt voor de gehele glastuinbouw. De negatieve effecten op de kosten van de productie van duurzame energie en het gebruik van energiebesparende technieken komen voort uit de extra ODE-kosten voor het extra elektriciteitsgebruik door de duurzame energiebronnen en energiebesparende technieken.

De directe effecten op de reductie van de $\mathrm{CO}_{2}$-emisssie zijn globaal gekwantificeerd en de indirecte effecten zijn niet gekwantificeerd. De kwantificering heeft plaatsgevonden met als referentie de prognoses van de $\mathrm{CO}_{2}$-emissie van de glastuinbouw in 2030 (Van der Velden et al., 2018). In deze prognose zijn 3 scenario's ontwikkeld (paragraaf 3.3).

De invloed van de directe effecten, het gelijk blijven van het vermogen van de wkk's per $\mathrm{m}^{2}$ en de hiermee samenhangende verminderde warmtebesparing, bij bedrijven met belichting loopt in de afzonderlijke scenario's in de prognose van de $\mathrm{CO}_{2}$-emissie van de glastuinbouw in 2030 uiteen van 0,5 tot 0,7 Mton (tabel 3.1). In procenten loopt de vermindering van de reductie van de $\mathrm{CO}_{2}$-emissie uiteen van 15 tot $27 \%$.

De invloed van dit directe effect, het gebruik van een kleine wkk door grote bedrijven zonder belichting, bedraagt in de afzonderlijke scenario's circa 1 tot $2 \mathrm{kton}$. Dit is meer dan een factor duizend kleiner dan de invloed van het voorgaande directe effect en is daardoor verwaarloosd.

De indirecte effecten zijn in deze studie niet gekwantificeerd en kunnen een grotere impact hebben doordat deze effecten zich niet beperken tot de bedrijven met belichting maar relevant zijn voor de gehele glastuinbouw en ook daarbuiten.

Tabel 3.1 Globale effecten van de directe effecten op de reductie van de $\mathrm{CO}_{2}$-emissie in 2030 van de glastuinbouw in de 3 scenario's a)

\begin{tabular}{|c|c|c|c|c|}
\hline & & \multicolumn{3}{|c|}{ Scenario } \\
\hline & & pessimistische & gematigd & optimistisch \\
\hline $\begin{array}{l}\text { Reductie } \mathrm{CO}_{2} \text {-emissie voor direct } \\
\text { effect }\end{array}$ & Mton & 3,14 & 2,83 & 2,59 \\
\hline Direct effect op reductie & Mton & $-0,47$ & $-0,57$ & $-0,70$ \\
\hline $\begin{array}{l}\text { Reductie } \mathrm{CO}_{2} \text {-emissie na direct } \\
\text { effect }\end{array}$ & Mton & 2,67 & 2,26 & 1,89 \\
\hline Vermindering reductie $\mathrm{CO}_{2}$-emissie & $\%$ & 15 & 20 & 27 \\
\hline
\end{tabular}

door direct effect

a) Bron: Prognoses $\mathrm{CO}_{2}$-emissie glastuinbouw 2030 (Van der Velden et al., 2018)

$\mathrm{Bij}$ deze kwantificering van de directe effecten op de reductie van de $\mathrm{CO}_{2}$-emissie is het relevant dat het areaal op bedrijven met belichting toeneemt. In de huidige situatie omvat het areaal met belichting circa $30 \%$ en in de prognose 2030 circa $40 \%$ van het totale glastuinbouwareaal. In de prognose 2030 neemt dit laatste toe tot circa 50\% van het totale glastuinbouwareaal. De bedrijven met belichting hebben in 2018 een aandeel van circa $50 \%$ in de $\mathrm{CO}_{2}$-emissie van de glastuinbouw en in de prognose 2030 loopt dit op tot 70 of $90 \%$. 


\section{Conclusies}

\section{Kosteneffect sectorniveau}

- Door de veranderingen van de ODE-tarieven op inkoop van elektriciteit in 2020 nemen de kosten van de glastuinbouwsector met minimaal $€ 30$ miljoen toe. De ODE-kosten voor elektriciteit stijgen daardoor van minimaal $€ 19$ miljoen in 2019 naar minimaal $€ 49$ miljoen in 2020.

- De gemiddelde stijging van de ODE-kosten elektriciteit per vestiging bedraagt in 2020 naar schatting $€ 9.300(+153 \%)$ en circa 32 €cent per $\mathrm{m}^{2}$.

- Op basis van de verwachte tarieven voor 2025 nemen de ODE-kosten ten opzichte van 2019 toe met minimaal $€ 46$ miljoen. De gemiddelde kostenstijging per vestiging in 2025 bedraagt $€ 14.300$ (+235\%). In 2025 liggen de verwachte extra kosten daarmee circa 50\% hoger dan in 2020. De kostenstijging door de tariefwijziging van de ODE is dus structureel.

- Op sectorniveau zijn de gemiddelde effecten van de toename van de ODE-kosten elektriciteit beperkt van omvang. Echter, door de grote verschillen tussen de afzonderlijke vestigingen geeft dit een onvolledig inzicht in de effecten op bedrijfsniveau.

\section{Kosteneffecten bedrijfsniveau}

- Vestigingen met belichting worden geconfronteerd met de hoogste en vestigingen zonder belichting met de laagste kostenstijging. Dit geldt zowel voor de situatie met als zonder wkk.

- De gemiddelde extra ODE-kosten liggen voor de vestigingen met belichting een factor 24 hoger dan bij de vestingen zonder belichting.

- Voor vestigingen zonder belichting (78\% van de vestigingen en $60 \%$ van het areaal) bedraagt de kostenstijging in 2020 gemiddeld $€ 1.500$ ( $+95 \%$ ), uiteenlopend van $€ 0$ tot $€ 29.000$ ( $+166 \%$ ).

- Voor vestigingen met belichting ( $22 \%$ van de vestigingen en $40 \%$ van het areaal) bedraagt de kostenstijging in 2020 gemiddeld $€ 36.500$ ( $+167 \%)$, uiteenlopend van $€ 200(+39 \%)$ tot $€ 136.000$ $(+175 \%)$

- Binnen de groep met belichting heeft $69 \%$ van de vestigingen met daarop $88 \%$ van het areaal extra ODE-kosten die boven het gemiddelde van de gehele sector liggen ( $€ 51.000$ ten opzichte van $€$ 9.300). Voor het grootste deel van het areaal met belichting zijn de kosteneffecten dus substantieel.

- Een deel van de bedrijven heeft meerdere vestigingen. Voor deze bedrijven ligt de absolute kostenstijging evenredig hoger en de relatieve kostenstijging beperkt hoger. Dit laatste komt doordat de ODE-kosten voor de bedrijven met meerdere vestigingen in 2019 al hoger waren.

- Binnen de gehele glastuinbouwsector heeft $17 \%$ van de vestigingen met daarop $48 \%$ van het areaal extra ODE-kosten die boven het gemiddelde van de gehele sector liggen ( $€$ 9.300).

- Bij alle vier de subgroepen, zonder en met belichting en daarbinnen zonder en met wkk, heeft circa een derde van de vestingen met daarop circa tweederde van het areaal een kostenstijging die boven het gemiddelde per subgroep ligt. De gemiddelde kostenstijging voor deze vestigingen ligt ruim 2 maal hoger dan het gemiddelde per subgroep.

- Vestigingen die vergaande of volledige reductie van de $\mathrm{CO}_{2}$-emissie hebben gerealiseerd kopen meer elektriciteit in. Dit komt door de extra elektriciteit die nodig is voor duurzame energiebronnen en energiebesparende technieken, maar ook doordat elektriciteit die in de referentie opgewekt werd met wkk en nu ingekocht moet worden. Dit brengt voor de meeste vestigingen substantiële extra ODE-kosten met zich mee in vergelijking met gangbare vestigingen. De extra ODE-kosten liggen voor de voorlopers gemiddeld $262 \%$ hoger dan in de referentiesituatie.

- In 2025 zijn de extra kosten ten opzichte van 2019 voor de vestigingen met belichting gemiddeld $€ 55.500(+254 \%)$ en voor de vestigingen zonder belichting gemiddeld $€ 2.500(+159 \%)$. Dit is respectievelijk 52\% en $67 \%$ hoger dan de kostenstijging in 2020.

\section{Effecten rentabiliteit en bedrijfsresultaat}

- Door de hogere ODE-kosten op inkoop van elektriciteit nemen de totale kosten van de glastuinbouwbedrijven toe met gemiddeld met 0,6\%. De netto-energiekosten stijgen met gemiddeld 
$4 \%$. De gemiddelde rentabiliteit zal met 0,6 procentpunt dalen en het gemiddelde netto bedrijfsresultaat met $6 \%$.

- Bij de bedrijven met belichting zijn de effecten op de kosten en de economische bedrijfsresultaten beduidend groter dan het gemiddelde van alle bedrijven en van de bedrijven zonder belichting. In de subgroep met belichting liggen de effecten bij de genoemde kentallen een factor 5 tot 10 ongunstiger ten opzichte van de subgroep zonder belichting. Bij de laatste groep daalt het bedrijfsresultaat met circa $2 \%$ en bij de eerste groep met circa $11 \%$.

- De vestigingen met belichting bij de gewassen chrysant, Lisianthus, roos en tomaat worden geconfronteerd met de grootste kostenstijging. Het aandeel van de extra kosten in de omzet loopt bij deze gewassen uiteen van bijna $1 \%$ tot ruim $2 \%$. Deze aandelen liggen een factor 1,5 tot 4 hoger in vergelijking met de gemiddelde kostenstijging in de gehele bedrijfstak $(0,6 \%)$ en ook hoger in vergelijking met alle bedrijven met belichting. Dit betekent dat de bedrijfsresultaten bij deze gewassen met intensieve belichting sterker negatief worden beïnvloed.

\section{Effecten reductie $\mathrm{CO}_{2}$-emissie}

- De verhoging van de ODE-kosten voor inkoop van elektriciteit heeft impact op diverse aspecten die van invloed zijn op het reduceren van de $\mathrm{CO}_{2}$-emissie. Deze impact zit vooral bij bedrijven met belichting.

- De bedrijven kunnen regeren op de kostenstijging door vooral extensivering van de belichting en extra gebruik van de wkk's. De mogelijkheden van deze twee opties zijn door verstoringen in de afzetmarkt en mogelijke benutting van de geproduceerde wkk-warmte echter beperkt.

- Door de verhoging van de ODE-kosten op elektriciteit zal de eigen productie van elektriciteit met wkk steviger verankerd blijven. Hierdoor zal de ingezette transitie naar uitfasering van wkk in combinatie en gewenste toename van inkoop van elektriciteit, het gebruik van duurzame warmte en/of de inkoop van warmte worden geremd. Doordat bestaande wkk's gereviseerd of vervangen zullen worden door nieuwe geldt dit voor een langere periode tot na 2030.

- Op bedrijven met belichting zullen de vermogens van de wkk's per $\mathrm{m}^{2}$ kas niet dalen. Hierdoor komt de reductie van de warmtevraag door energiebesparing in de knel.

- Reductie van de $\mathrm{CO}_{2}$-emissie door energiebesparing en productie van duurzame energie brengt extra elektriciteitsgebruik en dus extra ODE-kosten met zich mee. Ook dit is een rem op de reductie van de $\mathrm{CO}_{2}$-emissie. Het is mogelijk dat de voorlopers bij de reductie van de $\mathrm{CO}_{2}$-emissie de gerealiseerde transitiestappen daardoor terugdraaien.

- Voor samenwerkingspartners die nodig zijn voor het realiseren van energievoorzieningen zonder $\mathrm{CO}_{2}$-emissie en bijbehorende energie-infrastructuur vermindert de hoeveelheid af te zetten warmte en ook de waarde hiervan. Hiermee vermindert het investeringsperspectief en het animo voor participatie.

- Door de negatieve effecten op de energiebesparing en op de ontwikkeling en het gebruik van energievoorziening zonder $\mathrm{CO}_{2}$-emissie is het effect van de kostenstijging van de ODE op inkoop van elektriciteit tegengesteld aan de gewenste reductie van de $\mathrm{CO}_{2}$-emissie van glastuinbouw. De reductie van de $\mathrm{CO}_{2}$-emissie zal daardoor stagneren en mogelijk kan de $\mathrm{CO}_{2}$-emissie zelfs toenemen.

- Deze toekomstige ontwikkeling wordt versterkt door de negatieve invloed van de stijging op de ODE-kosten op het bedrijfsresultaat van vooral de bedrijven met belichting waardoor deze bedrijven minder kunnen investeren.

- Het directe kwantitatieve effect van het niet verminderen van de vermogens van de wkk's per $\mathrm{m}^{2}$ kas op bedrijven met belichting en de hiermee samenhangende vermindering van de warmtebesparing, op de reductie van de $\mathrm{CO}_{2}$-emissie loopt globaal uiteen van minus 0,5 tot minus 0,7 Mton. Dit is 15 tot $27 \%$ van de geprognotiseerde reductie van de $\mathrm{CO}_{2}$-emissie van de glastuinbouw in 2030 . 


\section{Literatuur en websites}

Brief van de Staatssecretaris van Economische Zaken, de heer Martijn van Dam, aan de voorzitter van de Tweede Kamer betreffende Evaluatie $\mathrm{CO}_{2}$-sturing in de glastuinbouw, dd. 6 juli 2017.

Convenant $\mathrm{CO}_{2}$ emissieruimte binnen het $\mathrm{CO}_{2}$ sectorsysteem glastuinbouw voor de periode 20132020. 2011.

Meerjarenafspraak Energietransitie Glastuinbouw 2014-2020, Den Haag, 2014

Smit, P.X. en N.J.A. van der Velden, Energiebenutting warmtekrachtkoppeling in de Nederlandse glastuinbouw. Rapport 2008-019. LEI Wageningen UR, Den Haag, 2008.

Velden, N.J.A. van der en P.X. Smit, Groei elektriciteitsconsumptie glastuinbouw; Hoe verder? Rapport 2013-022. LEI Wageningen UR, Den Haag, 2013.

Velden, N. van der, H. Silvis, M. Blom en M. Smit, Evaluatie energiebelastingtarief glastuinbouw. Rapport 2016-027. LEI Wageningen UR, Den Haag, 2016.

Velden, N.J.A. van der en P.X. Smit, Effect intensivering, extensivering en energiebesparing op $\mathrm{CO}_{2}{ }^{-}$ emissie Nederlandse glastuinbouw. Rapport 2017-060. Wageningen Economic Research, 2017

Velden, N.J.A. van der, P.X. Smit en J.S. Buurma, Prognoses $\mathrm{CO}_{2}$-emissie glastuinbouw 2030. Rapport 2018-056. Wageningen Economic Research, 2018.

Velden, N.J.A. van der en P.X. Smit, $\mathrm{CO}_{2}$-behoefte glastuinbouw 2030. Rapport 2019-074. Wageningen Economic Research, Wageningen, 2019a.

Velden, N.J.A. van der en P.X. Smit, Energiemonitor van de Nederlandse Glastuinbouw 2018. Rapport 2019-111, Wageningen Economic Research, Wageningen, 2019b.

Velden, N.J.A. van en P.X. Smit, Protocol Energiemonitor Glastuinbouw; Versie tot en met 2018. Nota 2019-111a, Wageningen Economic Research, Wageningen, 2019c.

Websites

- www.agrimatie.nl

- www.kasalsenergiebron.nl 


\section{Bijlage 1 Tarieven ODE}

Tabel B1.1 ODE-tarieven inkoop elektriciteit 2018, 2019, 2020 en de verwachting voor 2025

\begin{tabular}{|c|c|c|c|c|c|c|c|}
\hline \multicolumn{4}{|c|}{ Staffel } & \multicolumn{4}{|c|}{ Tarief (eurocent/ $\mathrm{m}^{3}$ ) } \\
\hline & $\begin{array}{r}\text { Ondergrens } \\
\text { (kWh) }\end{array}$ & $\begin{array}{r}\text { Bovengrens } \\
\text { (kWh) }\end{array}$ & $\begin{array}{r}\text { Verschil } \\
(\mathbf{k W h})\end{array}$ & 2018 & 2019 & 2020 & 2025 a) \\
\hline 1 & 0 & 10.000 & 10.000 & 1,320 & 1,89 & 2,73 & 3,63 \\
\hline 2 & 10.000 & 50.000 & 40.000 & 1,800 & 2,78 & 3,75 & 4,97 \\
\hline 3 & 50.000 & 10.000 .000 & 9.950 .000 & 0,480 & 0,74 & 2,05 & 2,72 \\
\hline 4 & 10.000 .000 & & & 0,019 & 0,03 & 0,04 & 0,05 \\
\hline
\end{tabular}

a) Bron 2025: EZK

Tabel B1.2 Verlaagde ODE-tarieven inkoop aardgas tuinbouw

\begin{tabular}{rrrrrrrr} 
& \multicolumn{5}{c}{ Stafiel } & \multicolumn{2}{c}{ Tarief (eurocent/ $\left.\mathrm{m}^{3}\right)$} \\
\hline & $\begin{array}{r}\text { Ondergrens } \\
\left(\mathrm{m}^{3}\right)\end{array}$ & $\begin{array}{r}\text { Bovengrens } \\
\left(\mathrm{m}^{3}\right)\end{array}$ & $\begin{array}{r}\text { Verschil } \\
\left(\mathrm{m}^{3}\right)\end{array}$ & 2018 & 2019 & 2020 & 2025 a) \\
\hline 1 & 0 & 170.000 & 170.000 & 0,46 & 8,40 & 1,24 & 1,65 \\
\hline 2 & 170.000 & 1.000 .000 & 830.000 & 0,40 & 0,61 & 0,81 & 1,07 \\
\hline 3 & 1.000 .000 & 10.000 .000 & 9.000 .000 & 0,39 & 0,59 & 2,12 & 2,81 \\
\hline 4 & 10.000 .000 & & & 0,21 & 0,31 & 2,12 & 2,91 \\
\hline
\end{tabular}

a) Bron 2025: EZK 


\section{Bijlage 2 Gewas(groep)indeling rekenmodel}

Tabel B2.1 In beschouwing genomen gewas(groepen) in het rekenmodel, het areaal per gewas(groep) in 2018 en het gebruik van belichting

\begin{tabular}{|c|c|c|}
\hline Gewas(groep) & Areaal (ha) & $\begin{array}{r}\text { Globaal aandeel bedrijven } \\
\text { met belichting a) }\end{array}$ \\
\hline \multicolumn{3}{|l|}{ Groente en fruit } \\
\hline Tomaat & 1.787 & 2 \\
\hline Paprika & 1.312 & 1 \\
\hline Komkommers & 563 & 1 \\
\hline Aubergine & 90 & 0 \\
\hline Aardbeien glas & 334 & 1 \\
\hline Aardbeien plastic tunnel & 67 & 0 \\
\hline Radijs & 74 & 1 \\
\hline Krop sla & 51 & 1 \\
\hline Overige groenten & 235 & 1 \\
\hline Fruit onder glas & 123 & 0 \\
\hline Groentezaden & 203 & 1 \\
\hline Opkweekmateriaal groenten & 271 & 2 \\
\hline \multicolumn{3}{|l|}{ Sierteelt } \\
\hline Rozen & 225 & 3 \\
\hline Chrysanten & 369 & 3 \\
\hline Gerbera & 156 & 3 \\
\hline Lelie & 114 & 3 \\
\hline Freesia & 61 & 3 \\
\hline Anjer & 8 & 0 \\
\hline Alstroemeria & 34 & 3 \\
\hline Anthurium & 40 & 2 \\
\hline Lisianthus & 28 & 3 \\
\hline Snijhortensia & 102 & 1 \\
\hline Amaryllis bloem & 85 & 0 \\
\hline Snijorchidee & 106 & 1 \\
\hline Overige snijbloemen en bloemkwekerij & 404 & 2 \\
\hline Opkweekmateriaal snijbloemen & 121 & 3 \\
\hline Bloemzaden & 15 & 2 \\
\hline Potplanten bloei & 723 & 2 \\
\hline Potplanten blad & 380 & 2 \\
\hline Phalaenopsis & 220 & 3 \\
\hline Perkplanten & 312 & 1 \\
\hline Boomkwekerij en vaste planten & 377 & 0 \\
\hline Totaal & 8.990 & 2 \\
\hline
\end{tabular}

$0=$ geen belichting; $1=<$ een derde; $2=$ tussen een derde en tweederde; $3=>$ twee derde Bron: LBT 


\section{Bijlage 3 Handelingsmogelijkheden}

\section{Toelichting}

Deze bijlage bevat een overzicht van mogelijke opties voor de ondernemers om te reageren op de toegekomen kosten voor inkoop van elektriciteit door de wijziging van de ODE-tarieven. De mogelijke opties zijn relevant voor vestigingen die geconfronteerd worden met de grootste extra kosten. Dit zijn vooral de vestigingen met belichting en in beperkte mate de grote bedrijven zonder belichting. Onderscheid is gemaakt naar mogelijke opties voor de korte termijn (KT, 1-2 jaar) en opties voor de middellange termijn (MT, 2-5 jaar). De mogelijke opties voor de KT zijn ook mogelijk voor de MT.

Mogelijke opties

- Stoppen met het bedrijf (KT)

- Stoppen met belichten (KT)

- Vestigingen samenvoegen (LT)

- Extensivering consumptie elektriciteit

- belichting (kortere gebruiksduur) (KT)

- overig elektrische apparatuur (kortere gebruiksduur) (KT)

- Besparing elektriciteit (efficiëntere apparatuur)

- belichting (selectiever belichten, ledlicht) (MT)

- overig elektrische apparatuur (MT)

- Meer eigen productie elektriciteit

- wkk-aardgas

- langere gebruiksduur (KT)

- extra wkk (MT) ${ }^{8}$

- duurzame productie elektriciteit (wkk-biobrandstof, zonne-PV, wind) (MT)

\section{Kanttekeningen}

- Het stoppen met het bedrijf of vestigingen samenvoegen zijn structurele maatregelen die samenhangen met meer factoren dan alleen de ODE-kosten.

- Bedrijven kunnen door de hogere extra ODE-kosten ook failliet gaan en dus stoppen of de stekker kan uit de financiering van bijvoorbeeld oogstkredieten worden getrokken. Voor beide geldt echter dat dit geen optie is door de bedrijven zelf.

- In de glastuinbouw is al decennialang een trend gaande naar meer belichting (areaal) en intensievere belichting (meer licht per $\mathrm{m}^{2}$ ). Deze ontwikkeling wordt veroorzaakt doordat de afzetmarkt vraagt om winderproductie met bijbehorende hoge prijzen. Dit proces kan worden afgeremd door de hogere kosten voor inkoop van elektriciteit. Door vraag vanuit de afzetmarkt en de hogere prijzen voor de glastuinbouwproducten in de winterperiode is de verwachting dat de trend naar meer en intensievere belichting zal doorzetten.

- Naast extensivering van de inzet van de belichting kan het elektriciteitsgebruik door belichting worden verminderd door besparing. Dit zou kunnen door ledlicht en door selectiever te belichten (Het Nieuwe Telen) en dus niet op tijdstippen waarop de belichting geen teeltkundig effect heeft. Door het gebruik van ledlicht zal eerder intensivering van de belichting optreden dan dat er minder elektriciteit wordt ingekocht. Rond het gebruik van ledlicht en het selectiever belichten voor het realiseren van besparing op de elektriciteitsconsumptie bestaan teeltkundige vragen waardoor de effecten op de toegenomen ODE-kosten in de praktijk op de korte termijn beperkt zal zijn.

- In de glastuinbouw is een trend gaande naar meer gebruik van overige elektrische apparatuur. Dit komt voort uit efficiëntere bedrijfsvoering (mechanisatie, automatisering, intern transport, enzovoort) en het creëren van een optimaal kasklimaat voor de gewassen. Dit proces kan worden afgeremd door de hogere kosten voor inkoop van elektriciteit. Het ligt echter voor de hand dat de efficiëntere bedrijfsvoering en het verder optimaliseren van het kasklimaat zich zal voortzetten.

\footnotetext{
${ }^{8}$ Bij de aanschaf van een nieuwe wkk heeft de ondernemer te maken met levertijden waardoor deze mogelijkheid vooral voor de middellange termijn een opties is.
} 
Wageningen Economic Research Postbus 29703

2502 LS Den Haag

T 0703358330

Ecommunications.ssg@wur.nl

www.wur.nl/economic-research

Wageningen Economic Research RAPPORT

2020-044
De missie van Wageningen University \& Research is 'To explore the potential of nature to improve the quality of life'. Binnen Wageningen University \& Research bundelen Wageningen University en gespecialiseerde onderzoeksinstituten van Stichting Wageningen Research hun krachten om bij te dragen aan de oplossing van belangrijke vragen in het domein van gezonde voeding en leefomgeving. Met ongeveer 30 vestigingen, 5.000 medewerkers en 12.000 studenten behoort Wageningen University \& Research wereldwijd tot de aansprekende kennisinstellingen binnen haar domein. De integrale benadering van de vraagstukken en de samenwerking tussen verschillende disciplines vormen het hart van de unieke Wageningen aanpak. 



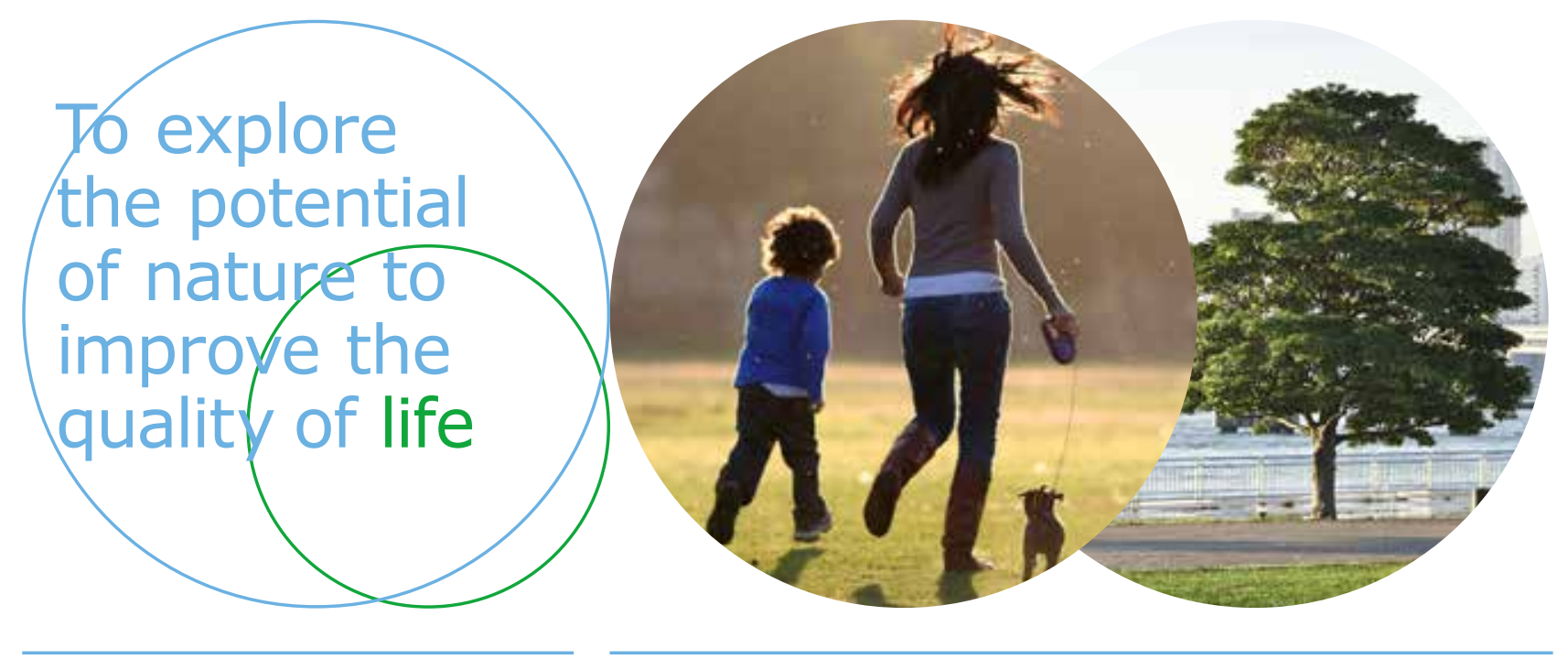

Wageningen Economic Research Postbus 29703

2502 LS Den Haag

T 0703358330

E communications.ssg@wur.nl www.wur.nl/economic-research

Rapport 2020-044

ISBN 978-94-6395-412-9
De missie van Wageningen University \& Research is 'To explore the potential of nature to improve the quality of life'. Binnen Wageningen University \& Research bundelen Wageningen University en gespecialiseerde onderzoeksinstituten van Stichting Wageningen Research hun krachten om bij te dragen aan de oplossing van belangrijke vragen in het domein van gezonde voeding en leefomgeving. Met ongeveer 30 vestigingen, 5.000 medewerkers en 12.000 studenten behoort Wageningen University \& Research wereldwijd tot de aansprekende kennisinstellingen binnen haar domein. De integrale benadering van de vraagstukken en de samenwerking tussen verschillende disciplines vormen het hart van de unieke Wageningen aanpak. 